\title{
lncRNA and Mechanisms of Drug Resistance in Cancers of the Genitourinary System
}

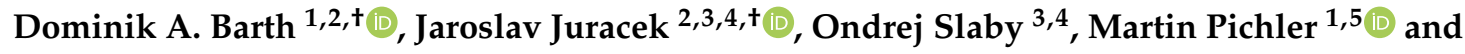 \\ George A. Calin 2,* \\ 1 Research Unit of Non-Coding RNAs and Genome Editing in Cancer, Division of Clinical Oncology, \\ Department of Medicine, Comprehensive Cancer Center Graz, Medical University of Graz, \\ 8036 Graz, Austria; dominik.barth@medunigraz.at (D.A.B.); martin.pichler@medunigraz.at (M.P.) \\ 2 Department of Translational Molecular Pathology, The University of Texas MD Anderson Cancer Center, \\ Houston, TX 77030, USA; juracekjaroslav@gmail.com \\ 3 Department of Comprehensive Cancer Care, Masaryk Memorial Cancer Institute, \\ 62500 Brno, Czech Republic; on.slaby@gmail.com \\ 4 Central European Institute of Technology, Masaryk University, 62500 Brno, Czech Republic \\ 5 Department of Experimental Therapeutics, The University of Texas MD Anderson Cancer Center, \\ Houston, TX 77030, USA \\ * Correspondence: gcalin@mdanderson.org \\ + These authors contributed equally to this work.
}

Received: 16 July 2020; Accepted: 30 July 2020; Published: 3 August 2020

\begin{abstract}
Available systemic treatment options for cancers of the genitourinary system have experienced great progress in the last decade. However, a large proportion of patients eventually develop resistance to treatment, resulting in disease progression and shorter overall survival. Biomarkers indicating the increasing resistance to cancer therapies are yet to enter clinical routine. Long non-coding RNAs (lncRNA) are non-protein coding RNA transcripts longer than 200 nucleotides that exert multiple types of regulatory functions of all known cellular processes. Increasing evidence supports the role of lncRNAs in cancer development and progression. Additionally, their involvement in the development of drug resistance across various cancer entities, including genitourinary malignancies, are starting to be discovered. Consequently, lncRNAs have been suggested as factors in novel therapeutic strategies to overcome drug resistance in cancer. In this review, the existing evidences on lncRNAs and their involvement in mechanisms of drug resistance in cancers of the genitourinary system, including renal cell carcinoma, bladder cancer, prostate cancer, and testicular cancer, will be highlighted and discussed to facilitate and encourage further research in this field. We summarize a significant number of lncRNAs with proposed pathways in drug resistance and available reported studies.
\end{abstract}

Keywords: lncRNA; drug resistance; chemoresistance; prostate cancer; renal cell carcinoma; bladder cancer; seminoma

\section{Introduction}

Cancers of the genitourinary system, including renal cell carcinoma (RCC), bladder cancer (BC), prostate cancer (PCa), and testicular cancer (TC) add up to being responsible for 626,000 cancer related deaths worldwide each year. Together they account for about $14 \%$ of all malignancies, respectively [1]. While TC has a comparably good prognosis even in metastatic treatment settings, outcomes for RCC, BC, and PCa strongly vary depending on tumor stage and clinico-pathological biomarkers [2]. However, because of the introduction and availability of novel drugs such as second generation antiandrogens in castration resistant PCa (CRPC) [3] or immune checkpoint inhibitors in BC and 
RCC $[4,5]$, outcomes are improving. Yet, resistance to systemic cancer therapy is a great obstacle in cancer treatment and represents a complex process involving genetic and epigenetic mechanisms. Insensitivity to systemic cancer treatment may be divided into intrinsic, i.e., resistance is present before any treatment, and acquired resistance by selection pressure [6].

Long non-coding RNAs (lncRNA) are non-protein coding RNA molecules with a length of more than 200 nucleotides and exert regulatory function in various cellular processes [7-12]. Briefly, a lncRNA may act as a signal, guide, decoy or scaffold for other non-coding RNAs or proteins and thereby alter various cellular functions [13]. In cancer, lncRNAs can act as both tumor suppressors and oncogenes and their involvement in cancer development and progression, including in genitourinary cancers, was repeatedly demonstrated [14].

In this review, we give a comprehensive overview of the existing evidence on the mechanisms of drug resistance involving lncRNAs in cancers of the genitourinary system as they may represent future therapeutic targets (Table 1). 
Table 1. Long non-coding RNAs (lncRNAs) associated with drug resistance in cancers of the genitourinary system: Abbreviations: RCC- renal cell carcinoma,

OS-overall survival, PFS—-progression free survival, DFS—disease-free survival, BRFS—biochemical recurrence free survival, NA—not applicable.

\begin{tabular}{|c|c|c|c|c|c|c|c|c|c|c|c|c|c|}
\hline IncRNA & $\begin{array}{c}\text { Drug } \\
\text { Resistance }\end{array}$ & $\begin{array}{l}\text { nfluence on } \\
\text { Resistance } \\
\uparrow / \downarrow\end{array}$ & $\begin{array}{l}\text { Expression } \\
\text { Pattern }\end{array}$ & Pathway & $\begin{array}{c}\text { Patient } \\
\text { Tissue }\end{array}$ & $\begin{array}{l}\text { In Vivo } \\
\text { Models }\end{array}$ & $\begin{array}{l}\text { Clinical } \\
\text { Endpoint }\end{array}$ & $\begin{array}{c}\text { Outcome } \\
\text { (High Expression) }\end{array}$ & $\begin{array}{l}\text { Cohort } \\
\text { Size }\end{array}$ & Database & $\begin{array}{c}\text { Multivariate } \\
\text { Analysis }\end{array}$ & $\begin{array}{c}\text { Hazard Ratio } \\
\text { (HR) (95\%CI, } \\
p \text {-Value) }\end{array}$ & Ref \\
\hline \multicolumn{14}{|c|}{ RCC } \\
\hline SRLR & Sorafenib & $\uparrow$ & $\uparrow$ & $\begin{array}{c}\text { SRLR/ } \\
\text { NF-KB/ } \\
\text { IL-6/ } \\
\text { STATA3 }\end{array}$ & Yes & Yes & $\begin{array}{l}\text { PFS, } \\
\text { treatment } \\
\text { response }\end{array}$ & Poor & 161 & Institutional & Yes & $\begin{array}{l}\text { PFS: } 0.407 \\
(0.222-0.744, \\
p=0.003)\end{array}$ & [15] \\
\hline ARSR & Sunitinib & $\uparrow$ & $\uparrow$ & $\begin{array}{c}\text { ARSR/ } \\
\text { miR-34/ } \\
\text { AXL } \\
\text { ARSR/ } \\
\text { miR-34/ } \\
\text { c-MET }\end{array}$ & Yes & Yes & $\begin{array}{l}\text { PFS, } \\
\text { treatment } \\
\text { response }\end{array}$ & Poor & 84 & Institutional & Yes & $\begin{array}{c}\text { PFS: } 2.9 \\
(1.2-7.1 \\
p=0.017)\end{array}$ & [16] \\
\hline ADAMTS9-AS2 & $\begin{array}{l}\text { 5-fluorouracile, } \\
\text { Cisplatin }\end{array}$ & $\downarrow$ & $\downarrow$ & $\begin{array}{l}\text { ADAMTS9-AS2/ } \\
\text { miR-27-3p/ } \\
\text { FOXO1 }\end{array}$ & yes & No & OS, DFS & Good & $\begin{array}{c}258 \\
76\end{array}$ & $\begin{array}{c}\text { GEIPA } \\
\text { Institutional }\end{array}$ & No & NA & [17] \\
\hline NEAT1 & Sorafenib & $\uparrow$ & $\uparrow$ & $\begin{array}{c}\text { NEAT1/ } \\
\text { miR-34a/ } \\
\text { c-MET }\end{array}$ & Yes & No & OS, PFS & Poor & 102 & Institutional & No & NA & [18] \\
\hline GAS5 & Sorafenib & $\downarrow$ & $\downarrow$ & $\begin{array}{l}\text { GAS5/ } \\
\text { miR-21/ } \\
\text { SOX5 }\end{array}$ & Yes & Yes & No & NA & NA & NA & NA & NA & [19] \\
\hline \multicolumn{14}{|c|}{ Bladder cancer } \\
\hline \multirow{3}{*}{ UCA1 } & Cisplatin/gemcitabin & ine $\uparrow$ & $\uparrow$ & $\begin{array}{c}\text { UCA1/ } \\
\text { CREB/ } \\
\text { miR-196a-5p/p27 }{ }^{\text {Kip1 }}\end{array}$ & Yes & Yes & No & NA & NA & NA & NA & NA & [20] \\
\hline & Cisplatin & $\uparrow$ & $\uparrow$ & $\begin{array}{l}\text { UCA1/Wnt6/Wnt } \\
\text { signaling }\end{array}$ & Yes & Yes & No & NA & NA & NA & NA & NA & [21] \\
\hline & NA & $\uparrow$ & $\uparrow$ & $\begin{array}{l}\text { UCA1/miR-582-5p/ } \\
\text { ATG7-autophagy }\end{array}$ & Yes & Yes & No & NA & NA & NA & NA & NA & [22] \\
\hline TUG1 & Cisplatin & $\uparrow$ & $\uparrow$ & $\begin{array}{l}\text { TUG1/miR-194-5p/ } \\
\text { CCND2 }\end{array}$ & Yes & Yes & OS & Poor & 87 & Institutional & No & NA & [23] \\
\hline PVT1 & $\begin{array}{l}\text { Doxorubicin/ } \\
\text { cisplatin }\end{array}$ & $\uparrow$ & $\uparrow$ & $\begin{array}{c}\text { PVT1/ } \\
\text { Wnt/ } \\
\beta \text {-catenin }\end{array}$ & Yes & No & No & NA & NA & Institutional & NA & NA & [24] \\
\hline FOXD2-AS1 & Gemcitabine & $\uparrow$ & $\uparrow$ & $\begin{array}{c}\text { FOXD2-AS1/miR-143/ } \\
\text { ABCC3 }\end{array}$ & No & Yes & No & NA & NA & NA & NA & NA & [25] \\
\hline
\end{tabular}


Table 1. Cont

\begin{tabular}{|c|c|c|c|c|c|c|c|c|c|c|c|c|c|}
\hline IncRNA & $\begin{array}{c}\text { Drug } \\
\text { Resistance }\end{array}$ & $\begin{array}{c}\text { Influence on } \\
\text { Resistance } \\
\uparrow / \downarrow\end{array}$ & $\begin{array}{l}\text { Expression } \\
\text { Pattern }\end{array}$ & Pathway & $\begin{array}{c}\text { Patient } \\
\text { Tissue }\end{array}$ & $\begin{array}{l}\text { In Vivo } \\
\text { Models }\end{array}$ & $\begin{array}{l}\text { Clinical } \\
\text { Endpoint }\end{array}$ & $\begin{array}{c}\text { Outcome } \\
\text { (High Expression) }\end{array}$ & $\begin{array}{l}\text { Cohort } \\
\text { Size }\end{array}$ & Database & $\begin{array}{c}\text { Multivariate } \\
\text { Analysis }\end{array}$ & $\begin{array}{c}\text { Hazard Ratio } \\
\text { (HR) (95\%CI, } \\
p \text {-Value) }\end{array}$ & $\operatorname{Re}$ \\
\hline DLEU1 & Cisplatin & $\uparrow$ & $\uparrow$ & $\begin{array}{c}\text { DLEU1/miR-99b/ } \\
\text { HS3ST3B1 }\end{array}$ & Yes & No & OS & Poor & $\begin{array}{l}406 \\
485\end{array}$ & $\begin{array}{c}\text { TCGA } \\
\text { (UALCAN/ } \\
\text { KMplotter) }\end{array}$ & No & $\begin{array}{c}\text { OS: } 1.65 \\
(1.2-2.26) \\
p=0.0016\end{array}$ & {$[26$} \\
\hline MST1P2 & Cisplatin & $\uparrow$ & $\uparrow$ & $\begin{array}{l}\text { MST1P2/ } \\
\text { miR-133b/ } \\
\text { Sirt1/p53 }\end{array}$ & No & No & No & NA & NA & $\mathrm{NA}$ & NA & NA & {$[27$} \\
\hline HIF1A-AS2 & Cisplatin & $\uparrow$ & $\uparrow$ & $\begin{array}{l}\text { HIF1A-AS2/HMGA1/ } \\
\text { p53 family }\end{array}$ & Yes & No & No & NA & NA & NA & NA & NA & {$[28$} \\
\hline GHET1 & Gemcitabine & $\uparrow$ & $\uparrow$ & GHET1/ABCC1 & Yes & No & No & NA & NA & NA & NA & NA & {$[29$} \\
\hline MALAT1 & Cisplatin & $\uparrow$ & $\uparrow$ & $\begin{array}{l}\text { MALAT1/miR-101-3p/ } \\
\text { VEGF-C }\end{array}$ & Yes & No & No & NA & NA & NA & NA & NA & {$[30$} \\
\hline lncRNA-LET & Gemcitabine & $\downarrow$ & $\downarrow$ & $\begin{array}{c}\text { LncRNA-LET/NF90/ } \\
\text { miR-145 }\end{array}$ & Yes & Yes & OS & Good & 60 & Institutional & No & $p=0.0014$ & {$[31$} \\
\hline GAS5 & Doxorubicin & $\downarrow$ & $\downarrow$ & $\begin{array}{l}\text { GAS5/ } \\
\text { Bcl-2 }\end{array}$ & Yes & No & OS & Good & 82 & Institutional & No & $\begin{array}{c}\text { OS: } 0.4824 \\
(0.2865-0.8122 \\
p=0.006)\end{array}$ & {$[32$} \\
\hline LBCS & Cisplatin/gemcitabine & ine $\downarrow$ & $\downarrow$ & $\begin{array}{c}\operatorname{lnc}-\mathrm{LBCS} / \\
\text { hnRNPK/EZH2/ } \\
\text { SOX2 }\end{array}$ & Yes & Yes & OS, DFS & Good & $120 / 185$ & $\begin{array}{l}\text { Institutional } \\
\text { TCGA-GEPIA }\end{array}$ & Yes & $\begin{array}{c}\text { OS: } 0.2721 \\
p<0.0001 \\
\text { DFS: } 0.3029 \\
p<0.0001 \\
\text { OS: } 0.3663 \\
p=0.0165\end{array}$ & {$[33$} \\
\hline \multicolumn{14}{|c|}{ Prostate cancer } \\
\hline UCA1 & Docetaxel & $\uparrow$ & $\uparrow$ & $\begin{array}{c}\text { UCA1/ } \\
\text { miR-204 } \\
\text { /Sirt1 }\end{array}$ & No & No & No & NA & NA & NA & NA & NA & {$[34$} \\
\hline CASC2 & Docetaxel & $\downarrow$ & $\downarrow$ & CASC2/miR-183/SPRY2 & Yes & No & No & NA & NA & $\mathrm{NA}$ & NA & $\mathrm{NA}$ & {$[35$} \\
\hline \multirow[t]{2}{*}{ MALAT1 } & Docetaxel & $\uparrow$ & $\uparrow$ & $\begin{array}{l}\text { MALAT1/miR-145-5p/ } \\
\text { AKAP12 }\end{array}$ & Yes & Yes & No & NA & NA & NA & NA & NA & {$[36$} \\
\hline & Enzalutamide & $\uparrow$ & $\uparrow$ & MALAT1/SF2/AR-v7 & No & Yes & No & NA & NA & NA & NA & NA & {$[37$} \\
\hline Linc00673 & $\begin{array}{l}\text { Paclitaxel } \\
\text { Docetaxel }\end{array}$ & $\uparrow$ & $\uparrow$ & $\begin{array}{c}\text { Linc00673/Dnmt1-3/ } \\
\text { KFL4 }\end{array}$ & Yes & Yes & No & NA & NA & NA & NA & NA & {$[38$} \\
\hline Linc00518 & Paclitaxel & $\uparrow$ & $\uparrow$ & $\begin{array}{l}\text { Linc00518/miR-216-5p/ } \\
\text { GATA6 }\end{array}$ & Yes & No & OS & Poor & 45 & Institutional & No & NA & {$[39$} \\
\hline CCAT1 & Paclitaxel & $\uparrow$ & $\uparrow$ & $\begin{array}{l}\text { CCAT1/miR-24-3p/ } \\
\text { FSCN1 }\end{array}$ & Yes & No & No & NA & NA & NA & NA & NA & {$[40$} \\
\hline
\end{tabular}


Table 1. Cont.

\begin{tabular}{|c|c|c|c|c|c|c|c|c|c|c|c|c|c|}
\hline lncRNA & $\begin{array}{c}\text { Drug } \\
\text { Resistance }\end{array}$ & $\begin{array}{c}\text { Influence on } \\
\text { Resistance } \\
\uparrow / \downarrow\end{array}$ & $\begin{array}{l}\text { Expression } \\
\text { Pattern }\end{array}$ & Pathway & $\begin{array}{l}\text { Patient } \\
\text { Tissue }\end{array}$ & $\begin{array}{l}\text { In Vivo } \\
\text { Models }\end{array}$ & $\begin{array}{l}\text { Clinical } \\
\text { Endpoint }\end{array}$ & $\begin{array}{c}\text { Outcome } \\
\text { (High Expression) }\end{array}$ & $\begin{array}{l}\text { Cohort } \\
\text { Size }\end{array}$ & Database & $\begin{array}{l}\text { Multivariate } \\
\text { Analysis }\end{array}$ & $\begin{array}{c}\text { Hazard Ratio } \\
\text { (HR) (95\%CI, } \\
p \text {-Value) }\end{array}$ & $\operatorname{Re}$ \\
\hline DANCR & Docetaxel & $\uparrow$ & $\uparrow$ & $\begin{array}{l}\text { DANCR/miR-24a-5p/ } \\
\text { JAG1 }\end{array}$ & Yes & Yes & No & NA & NA & NA & NA & NA & {$[41$} \\
\hline HOXD-AS1 & $\begin{array}{l}\text { Bicalutamide } \\
\text { Paclitaxel }\end{array}$ & $\uparrow$ & $\uparrow$ & HOXD-AS1/WDR5 & No & Yes & PFS & Poor & 309 & TCGA & Yes & $\begin{array}{c}2.827 \\
(1.297-6.161) \\
p=0.009\end{array}$ & {$[42$} \\
\hline FEZF1-AS1 & Paclitaxel & $\uparrow$ & $\uparrow$ & $\begin{array}{l}\text { FEZF1-AS1/miR-25-3p/ } \\
\text { ITGB8 }\end{array}$ & Yes & Yes & No & NA & NA & NA & NA & NA & {$[43$} \\
\hline HOTTIP & Cisplatin & $\uparrow$ & $\uparrow$ & HOTTIP/Wnt/ $\beta$-catenin & Yes & No & No & NA & NA & NA & NA & NA & {$[44$} \\
\hline PCGEM1 & Enzalutamide & $\uparrow$ & $\uparrow$ & PCGEM1/AR3-splicing & No & Yes & No & NA & NA & NA & NA & NA & {$[45$} \\
\hline HOTAIR & Enzalutamide & $\uparrow$ & $\uparrow$ & HOTAIR/AR & Yes & No & BRFS & Poor & NA & GEO & No & NA & {$[46$} \\
\hline LBCS & Bicalutamide & $\downarrow$ & $\downarrow$ & $\begin{array}{c}\text { LBCS/ } \\
\text { hnRNPK/AR }\end{array}$ & Yes & No & $\begin{array}{l}\text { BRFS } \\
\text { PFS }\end{array}$ & Good & 374 & TCGA & Yes & $\begin{array}{c}\text { BRFS: } 0.447 \\
(0.235-0.967) \\
p=0.040\end{array}$ & {$[47$} \\
\hline \multicolumn{14}{|c|}{ Testicular Cancer } \\
\hline H19 & Cisplatin & $\uparrow$ & $\uparrow$ & H19/miR-106-5p/TDRG1 & Yes & Yes & No & NA & NA & NA & NA & NA & {$[48$} \\
\hline
\end{tabular}




\section{Long Non-Coding RNAs and Drug Resistance in Renal Cell Carcinoma}

According to the GLOBOCAN database, kidney cancer accounts for 338,000 of cancer diagnoses worldwide each year [1], making it the second and third most common cancer of the urogenital system in men and women, respectively. Ninety percent of malignancies of the kidney account for RCC, which is derived from the epithelium of renal tubules [49]. The most frequent pathological subtypes are clear cell (ccRCC), papillary RCC, and chromophobe RCC, which account for $70-80 \%, 10-15 \%$, and 3-5\%, respectively [50]. This traditional classification has become far more complex as RCCs can display various histological features of other subtypes and these novel molecular classifications bring new perspectives [51]. For localized disease, surgery represents the treatment of choice. However, some patients eventually experience recurrence and develop metastasis or already present with metastatic dissemination at the time of diagnosis. In these cases, palliative treatment systemic therapy is indicated. As RCC shows insufficient response to chemotherapy [52], immunotherapy with interleukin-2 and IFN $\alpha$ were some of the first agents used in the systemic treatment of RCC with only moderate success [53]. Novel targeted therapies such as the multikinase inhibitors sunitinib and sorafenib, which target vascular endothelial growth factor receptor (VEGFR) and platelet derived growth factor receptor (PDGFR) thereby inhibiting angiogenesis, improved these outcomes $[54,55]$. Nonetheless, the introduction of immune checkpoint inhibitors such as nivolumab, pembrolizumab and combinations with antiangiogenetic agents in the treatment of ccRCC drastically improved the outcome of metastatic RCC $[5,56]$. However, a significant number of patients still do not benefit from these novel therapeutic concepts and currently available predictive biomarkers, such as PD-L1 expression perform insufficiently [57]. Therefore, understanding the mechanisms of drug resistance is crucial. Importantly, intratumor heterogeneity plays an important role in treatment failures in RCC patients [58,59]. In RCC, lncRNAs were described to engage in pathogenesis and disease progression and were suggested as novel diagnostic tools [60]. However, although lncRNAs participate in the regulation of checkpoint inhibitors, studies investigating the development of resistance to checkpoint inhibitors in RCC are lacking [61,62]. To date, only data on lncRNAs and their role in in the development of resistance to multikinase inhibitors and chemotherapy are available.

\subsection{IncRNAs Promoting Drug Resistance in RCC}

\subsubsection{SRLR}

The sorafenib resistance-associated lncRNA in RCC (SRLR) was first functionally investigated by $\mathrm{Xu}$ et al. [15] who reported SRLR to promote resistance to treatment with the multi-kinase inhibitor sorafenib. Overexpression of SRLR was observed in RCC cells and the tissue of patients that were resistant to sorafenib. Mechanistically, SRLR directly interacts with the transcription factor $\mathrm{NF}_{-\mathrm{K}} \mathrm{B}$ which subsequently activates interleukin-6 (IL-6) transcription and autocrine IL-6 secretion in RCC cells. This results in the activation of the STAT3 pathway and sidesteps the inhibition of receptor tyrosine kinases such as VEGFR and PDGFR by sorafenib (Figure 1). This was experimentally confirmed both in vitro and in vivo [15]. The relationship of SLRL and IL-6 was only recently confirmed in a study investigating SRLR in polycystic ovary syndrome [63]. In a clinical dataset that included 95 RCC patients, higher expression levels of lncRNA SRLR were associated with reduced progression-free survival (PFS) $(\mathrm{HR}=0.407,95 \% \mathrm{CI}=0.222-0.744, p=0.003)$ and was additionally related to low benefit to treatment with sorafenib, and high levels of IL-6 [15].

\subsubsection{ARSR}

The lncRNA activated in RCC with sunitinib resistance (ARSR) significantly impacts resistance to treatment with the multikinase inhibitor sunitinib in RCC [16]. Mechanistically, by acting as a competing endogenous RNA (ceRNA), ARSR sequesters miR-34 and miR-449 and thus increases the levels of their targets AXL and c-MET, thereby promoting sunitinib resistance (Figure 1). ARSR is overexpressed in sunitinib resistant cells and reciprocally ARSR expression is increased by AXL through activation 
of FOXO transcriptional factors. This suggests a positive feedback loop between AXL and ARSR in sunitinib-resistant RCC. Interestingly, sunitinib resistance may also be transferred from cells resistant to sunitinib to sunitinib-sensitive cells via exosome-mediated transmission. Targeting of ARSR could be used as a novel therapeutic approach to overcome sunitinib resistance, as shown in in vivo and in vitro experiments [16]. Moreover, pretreatment ARSR levels in the plasma of RCC patients is significantly correlated with poor PFS for high vs. low ARSR expression (HR = 2.9, 95\% CI = 1.2-7.1, $p=0.017$ ), corroborating these findings [16]. A recent study also proposed single nucleotide polymorphisms (SNP) of the ARSR sequence as potential biomarkers for RCC outcome [64].

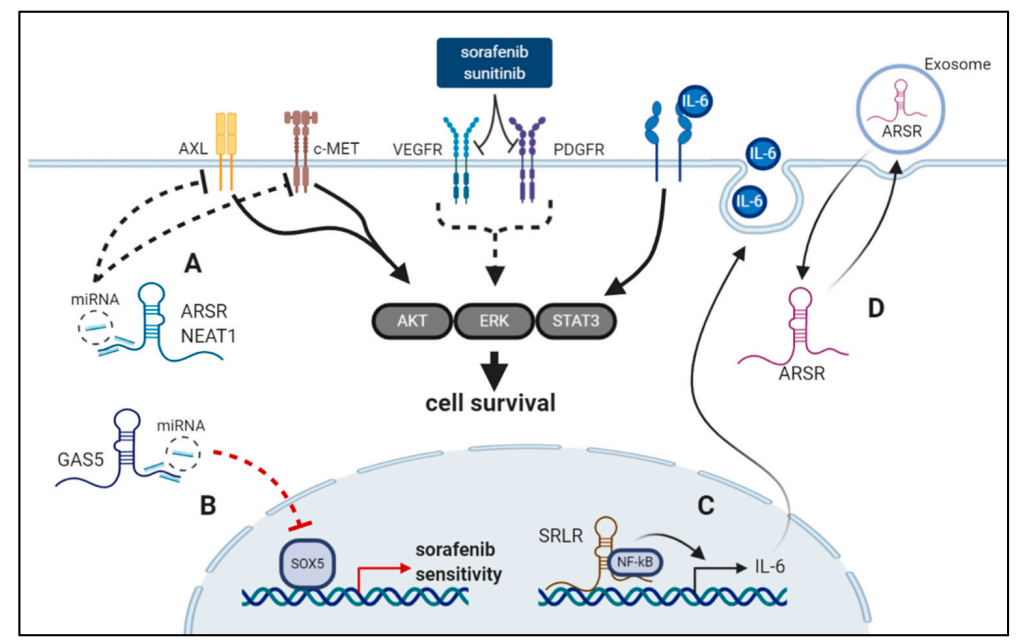

Figure 1. Examples of long non-coding RNAs (lncRNAs) and mechanisms of drug resistance in renal cell carcinoma (RCC). (A) lncRNA Nuclear Paraspeckle Assembly Transcript 1 (NEAT1) sponges miR-34a and as a result, increases c-MET expression. (B) lncRNA growth arrest specific transcript 1 (GAS5) sponges miR-21 thereby preventing it from targeting SRY-Box transcription factor 5 (SOX5) leading to increased sensitivity to sorafenib. (C) lncRNA sorafenib resistance-associated lncRNA in RCC (SRLR) recruits NF- $\mathrm{kB}$ to the interleukin 6 (IL-6) promoter, resulting in increased autocrine IL-6 secretion and bypassing of blocked vascular endothelial growth factor receptor (VEGFR) and platelet derived growth factor receptor (PDGFR). (D) lncRNA activated in RCC with sunitinib resistance (ARSR) can be secreted via exosomes from sunitinib resistant cells and can be incorporated from sunitinib sensitive cells, thereby transferring drug resistance. ARSR sponges miRNAs and consequently promotes AXL and c-MET expression promoting sunitinib resistance. (created with Biorender.com).

\subsubsection{NEAT1}

The nuclear paraspeckle assembly transcript 1 (NEAT1) and its function as an oncogenic lncRNA is already well investigated in multiple studies [65]. NEAT1 has been reported to promote resistance to chemotherapy $[66,67]$. In RRC, NEAT1 may inhibit response to sorafenib treatment by regulation of the NEAT1/miR-34a/c-MET axis by acting as a sponge for miR-34a [18] (Figure 1). Both, c-MET and miR-34a were already reported to impact chemoresistance in other cancer entities such as esophageal cancer and osteosarcoma [68-70]. Moreover, NEAT1 shows high expression in RCC cell lines and tissues. Additionally, overexpression of NEAT1 was correlated with epithelial-mesenchymal transition (EMT) and also significantly correlated with poor OS and PFS in RCC; although no uni- and multivariate analyses were implemented in the study by Liu et al., along with no xenograft models [18].

\subsection{IncRNAs Enhancing Drug Sensitivity in RCC}

\subsubsection{ADAMTS9-AS2}

The lncRNA ADAMTS9 antisense RNA 2 (ADAMTS9-AS2) was already reported to influence drug resistance in cancer. However, its role may vary depending on the cancer type as downregulation 
of ADAMTS9-AS2 in breast cancer was reported to increase tamoxifen resistance, whereas its downregulation was associated with increased sensitivity to temozolomide in glioblastoma [71,72]. In RCC, ADAMTS9-AS2 is downregulated and high expression is significantly associated with better OS [17]. By sequestering miR-27-3p, overexpression of ADAMTS9-AS2 resulted in increased FOXO1 expression and restored chemosensitivity to 5 -fluorouracil and cisplatin. However, confirmation in in vivo experiments is missing [17]. To date, chemotherapy is not a valid treatment option in RCC as it has proven ineffective, therefore the direct clinical impact of the study is limited [52]. However, targeting lncRNAs may overcome chemoresistance in RCC in the future and may establish chemotherapy as a valid treatment option in RCC.

\subsubsection{GAS5}

The lncRNA growth arrest specific transcript 1 (GAS5) was reported to influence RCC resistance to sorafenib in a study by Liu and colleagues [19]. The tumor suppressive role of GAS5 in RCC carcinogenesis and progression has already been repeatedly demonstrated [73]. In terms of its impact on sorafenib resistance, it was shown to act as a sponge for miR-21 and upregulation of GAS5 resulted in likewise upregulation of the transcription factor sex determining region Y-box protein 5 (SOX5), conferring increased sensitivity to sorafenib [19]. This was demonstrated by multiple in vitro and in vivo models. All effectors in the GAS5/miR-21/SOX5 pathway as proposed by Liu et al. [19] have already been reported to be effectors in chemoresistance individually, which corroborates these results [74-77].

\section{IncRNAs and Drug Resistance in Bladder Cancer}

With approximately 550,000 new cases in 2018, BC represents the seventh most frequent tumor type in our population [78]. The most common histological type is urothelial carcinoma (UC), accounting for approximately $90 \%$ of all bladder cancers. Other less frequent subtypes are squamous cell carcinoma and adenocarcinoma [79]. Based on the TNM classification and histopathological grading, two major subtypes of UC-non-muscle-invasive carcinoma (NMIBC; around 80\% at diagnosis) and muscle-invasive carcinoma (MIBC) are distinguished [80].

NMIBC is a heterogeneous disease with a good prognosis and curability, nevertheless around $70 \%$ of cases recur and about $10 \%$ progress into an invasive phenotype [81]. The standard-of-care for NMIBC currently is transurethral resection of bladder tumor (TURBT) with optional addition of intravesical therapy (mitomycin C, doxorubicin, gemcitabine, or BCG-Bacillus Calmette-Guerin) [82]. In the case of MIBC, the standard treatment protocol involves radical cystectomy with neoadjuvant or adjuvant chemotherapy with gemcitabine/cisplatin. Also, in metastatic disease which develops in $50 \%$ of MIBC cases, cisplatin-based chemotherapy in combination with gemcitabine remains the main therapeutic modality [83]. Moreover, novel treatment options such as immune checkpoint and fibroblast growth factor receptor (FGFR) inhibitors were introduced [4,84]. Despite recent advances in BC systemic treatment, eventual treatment resistance is responsible for cancer progression and death and its molecular mechanisms remain rather unclear. LncRNAs play a major part in BC pathophysiology $[14,85,86]$ and therefore are suggested as essential molecules in drug resistance. Further research of IncRNA involvement in BC chemoresistance may thus improve current treatment and reveal new therapeutic targets in $\mathrm{BC}$.

\subsection{IncRNAs Promoting Drug Resistance in BC}

\subsubsection{UCA1}

The lncRNA urothelial cancer-associated 1 (UCA1) plays an important role in BC tumorigenesis as shown by increased proliferation, invasion, migration, as well as therapy resistance of UC cell lines [86]. Regarding cisplatin chemoresistance, high expression of UCA1 in resistant cells significantly increases cell viability during cisplatin treatment. Moreover, overexpression positively regulates 
expression of Wnt6, subsequently activating Wnt signaling [21], which was previously connected with chemoresistance in cancer [87]. In addition to cisplatin, UCA1 was also studied in relation to gemcitabine resistance, where functioning via the UCA1/CREB/miR-196a-5p axis is proposed [20]. In this paradigm, UCA1 activates the AKT signaling pathway, which results in proto-oncogenic transcription factor CREB (cAMP response element-binding protein) phosphorylation. Active CREB then positively regulates expression of oncogenic miR-196a-5p (Figure 2) [20]. It has been shown that the suppression of miR-196a could attenuate resistance to cisplatin in lung cancer cell lines and relates to drug efflux-related proteins such as multidrug resistance1 (MDR1), multidrug resistance associated protein 1 (MRP1), endonuclease non-catalytic subunit (ERCC1), survivin, or Bcl-2 [88]. However, in BC, miR-196a-5p controls p27Kip1 expression by directly binding to its $3^{\prime}$ UTR [20]. As a cyclin-dependent kinase (CDK) inhibitor and activator of cleaved-caspase 3, p2 $7^{\mathrm{Kip} 1}$ can promote drug resistance via cell apoptosis [89]. Most recent reports showed a new regulatory network involving miR-582-5p and ATG7-mediated autophagy inhibition [22]. It is presumed that UCA1 serves as a miRNA sponge and binds mature miR-582-5p. Among miR-582-5p direct targets is also ATG7-an E1-like activating enzyme involved in autophagy [90], which is often activated as a protective mechanism of resistant cancer cells during chemotherapy [91]. Indeed, miR-582-5p-mediated suppression of ATG7 could inhibit autophagy, indicating the UCA1/miR-582-5p/ATG7 pathway regulates BC anti-cancer drug response [22].

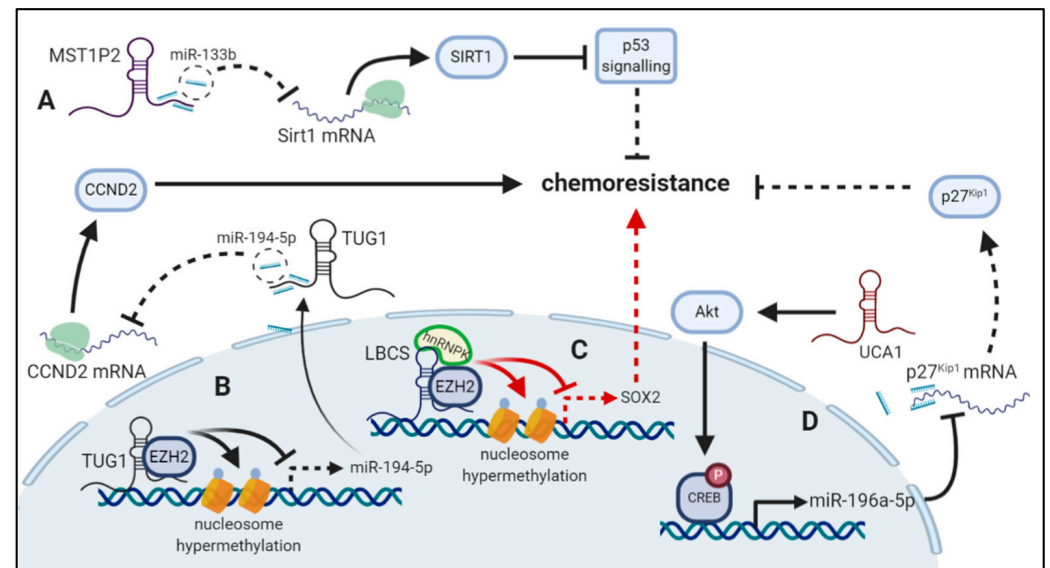

Figure 2. Examples of long non-coding RNAs (lncRNAs) and mechanisms of drug resistance in bladder cancer (BC). (A) lncRNA macrophage stimulating 1 pseudogene 2 (MST1P) sponges miR-133b thereby preventing it from targeting sirtuin 1 (Sirt1). This leads to increased Sirt1 expression and inhibition of p53 by Sirt1 and thus increased chemoresistance. (B) lncRNA taurine up-regulated 1 (TUG1) recruits enhancer of zeste homolog 2 (EZH2) to the miR-194-5p promoter resulting in hypermethylation and thus inhibited miR-194-5p transcription. Additionally, TUG1 sponges miR-194-5p preventing it from targeting cyclin D2 (CCND2) leading to increased expression and enhanced chemoresistance. (C) lncRNA low expressed in bladder cancer stem cells (LBCS) recruits EZH2 and heterogeneous nuclear ribonucleoprotein K (hnRNPK) to the SRY-box transcription factor 2 (SOX2) leading to hypermethylation and thereby inhibiting chemoresistance. (D) lncRNA urothelial cancer associated 1 (UCA1) activates the Akt-pathway and thereby enhances phosphorylation of cAMP response element-binding protein (CREB) transcription factor. CREB promotes the transcription of miR-196a-5p which targets $\mathrm{p} 27 \mathrm{Kip} 1$ tumor suppressor, leading to enhanced chemoresistance by UCA1 upregulation. (created with Biorender.com).

\subsubsection{TUG1}

Taurine-upregulated gene 1 (TUG1) is a lncRNA initially identified in the development of retina [92]. Recent findings have proven its association with various cancers; dysregulated expression level of TUG1 was described in colorectal cancer [93], gastric cancer [94], non-small cell lung cancer (NSCLC) [95], hepatocellular cancer [96], and BC [85,97]. Mechanisms enabling TUG1 to regulate cellular processes including chemoresistance were, for instance, described in lung cancer [95] though its biological function in BC is still unclear. Yu et al. [23] showed that TUG1 can induce the chemoresistance 
to cisplatin in BC through the TUG1/miR-194-5p/CCND2 axis. In detail, TUG1 influences miR-194-5p level via sponging mature miR-194-5p molecules and enhancer of zeste homolog 2 (EZH2)-related promoter methylation. Both ways lead to miR-194-5p down-regulation resulting in higher levels of its direct target cyclinD2 (CCND2) and thus chemoresistance to cisplatin promotion (Figure 2). Interestingly, this regulatory mechanism impacts proliferation and apoptosis of $\mathrm{BC}$ as well [23].

\subsubsection{PVT1}

Another chemoresistance-related lncRNA is plasmacytoma variant translocation 1 (PVT1). This $1716 \mathrm{nt}$ long transcript is overexpressed in various human cancers [98-100] and its regulative effect on chemosensitivity was already closely described in cervical cancer [98], gastric cancer [99] and lung cancer [100]. In BC, PVT1 overexpression was confirmed in chemo-resistant tissues, where it negatively correlates with response to cisplatin and doxorubicin. Also, in T24/DR cell lines, PVT1 knockdown reduced resistance to cisplatin and doxorubicin and led to suppression of MDR1 and MRP1 expression. Moreover, PVT1 suppression inhibits $W n t / \beta$-catenin signaling probably via miR-200b which is epigenetically silenced by PVT1. This proposed mechanism is supported by the observed restoration of chemoresistance in PVT1 knockdown T24/DR cells after $\beta$-catenin upregulation [24].

\subsubsection{FOXD2-AS1}

FOXD2 adjacent opposite strand RNA 1 (FOXD2-AS1) is an oncogenic cancer-related lncRNA, which was reported to be overexpressed in $\mathrm{BC}$ and was connected to tumor stage, recurrence as well as poor prognosis. FOXD2-AS1 promotes BC cell proliferation, migration, and invasion mainly via regulation of Tribbles pseudokinase 3 (TRIB3), which negatively regulates Akt [101]. Recently, a study by An et al. [25] described the involvement of FOXD2-AS1 in gemcitabine resistance of BC. In gemcitabine-resistant BC cells, a high level of this lncRNA led to the upregulation of known genes that are associated with drug resistance, such as MDR1, MRP2, LDL receptor-related protein 1 (LRP1), or ATP binding cassette subfamily $\mathrm{C}$ member 3 (ABCC3) protein [25]. The ABCC3 protein is demonstrably increased in $\mathrm{BC}$ cells and enhances cell proliferation, drug resistance, and aerobic glycolysis [102]. The bioinformatic analysis in this study then identified miR-143 as the intersection between FOXD2-AS1 and ABCC3, as miR-143 is predicted to target the ABCC3 3'-UTR and at the same time matched with FOXD2-AS13'-UTRs. Indeed, FOXD2-AS1 acted as a ceRNA miR-143 and thereby increased $\mathrm{ABCC} 3$ protein expression and accelerated gemcitabine resistance [25].

\subsubsection{DLEU1}

The deleted in lymphocytic leukemia 1 lncRNA (DLEU1) was discovered due to its location on chromosome 13q14.3, a region which is commonly deleted in chronic B-cell lymphocytic leukemia [103-105]. Beside DLEU1, this locus also hosts miR-15a and miR-16 which are the first ever discovered ncRNAs to be involved in human diseases [106-109]. Though in hematopoietic tumors DLEU1 can act as a potential tumor suppressor [110], in other cancers including cervical cancer [111], colorectal cancer [112], and NSCLC [113] it has been shown to exert oncogenic function. In BC, DLEU1 is significantly increased and induces cell proliferation, invasion, and cisplatin resistance. The mechanism involves sponging miR-99b [26], which was described as a tumor suppressive factor in multiple cancers [114,115]. The same function is suggested in BC where miR-99b shows significant downregulation [26] and targets, among other genes, FGFR3 [115] which is constitutively activated in NMIBC [116]. Sponging miR-99b by DLEU1 results in increased expression of oncogenic membrane protein HS3ST3B1 [26]. Although limited information about the exact function in BC is known, in other tumors HS3ST3B1 is associated mainly with EMT [117].

\subsubsection{MST1P2}

Association with resistance to cisplatin in $\mathrm{BC}$ was documented for macrophage stimulating 1 pseudogene 2 (MST1P2). MST1P2 was reported to be significantly upregulated in cisplatin-resistant 
BC cell lines where it serves as a ceRNA. Indeed, MST1P2 sponges miR-133b, where the expression level was downregulated in the same cell lines [27]. Interestingly, the participation of miR-133b in the regulation of chemoresistance was already described in ovarian cancer [118], colorectal cancer [119], and osteosarcoma [120]. Among direct targets of this short RNA is oncogene Sirt1 (Sirtuin 1) which was proposed as a possible effector of MST1P2/miR-133b mediated drug resistance [27]. Sirt1 overexpression can inactivate p53, which results in a low response of cancer cells with unmutated p53 to DNA-damaging chemotherapeutics [121] and thus inhibition of cancer cells apoptosis (Figure 2).

\subsubsection{HIF1A-AS2}

The hypoxia-inducible factor-1 alpha antisense RNA-2 (HIF1A-AS2) is a natural antisense transcript of hypoxia-inducible factor-1alpha (HIF-1 $\alpha$ ) which was suggested to play a crucial part in tumorigenesis, mainly via regulation of the HIF-1 $\alpha$ pathway [122]. In BC, HIF1A-AS2 displays an oncogenic function since it promotes cell proliferation, migration, and suppresses apoptosis [123]-however, the exact molecular regulatory mechanisms are yet to be elucidated. Interestingly, HIF1A-AS2 is highly upregulated also in cisplatin-resistant $\mathrm{BC}$ cells and tissues and contributes to BC cisplatin chemoresistance [28]. Previous reports in glioblastoma showed that HIF1A-AS2 interacts with proteins IGF2BP2 and DHX9 while enhancing the expression of their targets such as high mobility group AT-hook 1 (HMGA1) [124]. A similar mechanism takes place in BC drug resistance where HMGA1 overexpression facilitated by HIF1A-AS2 inhibits the transcriptional activity of p53 family proteins leading to cisplatin-induced apoptosis restraint [28].

\subsubsection{GHET1}

The oncogenic lncRNA gastric carcinoma proliferation-enhancing transcript 1 (GHET1) is upregulated in BC tissues, where its level is associated with tumor size, higher tumor stage, lymph node involvement, and adverse prognosis [125]. A recent report showed that GHET1 is also related to sensitivity to gemcitabine in BC. Based on statistics using TCGA (The Cancer Genome Atlas) datasets, a high level of GHET1 was correlated with increased expression of the ABCC1 gene, which is related to multidrug resistance [29]. This protein was already associated with chemotherapeutic resistance in BC [126], nevertheless, the exact mechanism of GHET1 regulation of the expression of ABCC1 is still unknown. However, it is presumed that the underlying mechanism involves regulation of miRNAs targeting $\mathrm{ABCC} 1$ as described in glioma, where GHET1 promoted a malignant phenotype through down-regulation of miR-216a [127].

\subsubsection{MALAT1}

Another IncRNA mediating cisplatin resistance in $\mathrm{BC}$ is metastasis-associated lung adenocarcinoma transcript 1 (MALAT1). Liu et al. [30] showed that this function is based on the regulation of the miR-101-3p/VEGF-C pathway. In detail, direct interaction between MALAT1 and miR-101-3p, which was demonstrated to be a tumor suppressor [128], impairs targeting and leads to VEGF-C overexpression [30]. This cytokine has been earlier described as a possible effector in $\mathrm{BC}$ chemoresistance via regulation of a mammary serine protease inhibitor maspin [129]. In addition, miR-101-3p reportedly enhances sensitivity of BC to cisplatin also by targeted silencing of EZH2 and MRP1 expression [130].

\subsection{IncRNAs Enhancing Drug Sensitivity in BC}

\subsubsection{IncRNA-LET}

The lncRNA-low expression in tumor (IncRNA-LET) was suggested to be involved in drug response in BC. As shown in the study of Zhuang et al. [31], gemcitabine treatment of chemoresistant urothelial cancer cells led to lncRNA-LET down-regulation and to the enrichment of cancer stem-like cell population. Subsequent deregulation of the lncRNA-LET/NF90/miR-145 pathway promoted stemness of cancer cells and led to chemoresistance. This complex mechanism is initiated by gemcitabine 
treatment-related upregulation of TGF $\beta 1$. Activation of TGF $\beta / S M A D$ signaling by SMAD binding element (SBE) in the IncRNA-LET promoter represses this lncRNA which results in greater stability of the NF90 protein [31]. Nuclear factor 90 (NF90) is a double-stranded RNA-binding protein participating in various cellular processes such as transcription, translation, or mRNA stabilization [131]. Interestingly, NF90 was also described as an adverse regulator in the miRNA processing pathway [132]. Indeed, in this case NF90 acts as competitor for the association of the microprocessor complex with pri-miR-145 resulting in miR-145 biogenesis inhibition. Subsequently, the downregulation of miR-145 leads to higher expression of cancer stemness regulatory genes Krüppel-like factor 4 (KLF4) and high-mobility group AT-hook 2 (HMGA2) [31] and thus chemoresistance. Direct regulation of KLF4 with miR-145 was reported previously in connection with the vascular smooth muscle cell phenotype [133].

\subsubsection{GAS5}

GAS5 participates in chemotherapeutic resistance to doxorubicin in urothelial carcinoma, although the underlying mechanism remains unclear. In BC cells resistant to doxorubicin, the GAS5 expression level was shown to be negatively correlated with the chemotherapy resistance to this drug [32]. Moreover, GAS5 overexpression positively correlated with apoptosis induced by doxorubicin treatment, as the repressed expression of anti-apoptotic protein Bcl-2 was observed. Inversely, upregulation of Bcl-2 reversed the inhibitory effect of GAS5 on chemoresistance to doxorubicin in chemo resistant cells [32]. This is no surprise, as GAS5 is notably known for apoptosis promotion, mainly via Bcl-2 suppression and caspase-3 upregulation, which is possibly facilitated through the miR-155 regulatory pathway [134].

\subsubsection{LBCS}

The lncRNA LBCS (low expressed in bladder cancer stem cells) acts as an important tumor suppressor in bladder cancer stem cells (BCSC) self-renewal and chemoresistance [33]. In addition to downregulation in $\mathrm{BC}$, its level associates with tumor grade, response to chemotherapy treatment, and prognosis. The chemoresistance suppression is executed by guiding the hnRNPK-EZH2 complex [33]. Heterogeneous nuclear ribonucleoprotein K (hnRNPK) is an important cancer-related RNA- and DNA-binding protein associated with poor prognosis in BC [135], while EZH2 is a histone methyltransferase that acts as an oncogene important for self-renewal [136]. As mentioned before, LBCS acts as a scaffold, thereby facilitating the formation of the hnRNPK/EZH2 complex. Subsequent recruitment of the complex to the SOX2 promoter mediates H3K27me3 and leads to SOX2 suppression [33]. A low level of LBCS therefore contributes to the upregulation of SOX2, a previously confirmed marker for stem-like tumor cells in BC [137] and thus to chemoresistance of BCSC (Figure 2).

\section{IncRNAs and Drug Resistance in Prostate Cancer}

PCa is the most frequent malignant tumor in males and the second most common cause for cancer-related death, accounting for $10 \%$ of all cancer deaths. In 2019, roughly 174,650 patients were confronted with a PCa diagnosis in the USA [138]. Depending on clinico-pathological risk factors, standard therapy options for curative non-metastatic stages include watchful waiting for low-risk PCa or radical prostatectomy and radiotherapy for PCa with high-risk features. Approximately $4 \%$ of PCa cases are diagnosed with primary metastatic disease and several patients experience distant recurrence in treatments with curative intention [139]. Standard systemic therapy in palliative settings are based on androgen deprivation therapy (ADT) [140]. Yet, a significant proportion of patients eventually progress on ADT and develop castration resistant PCa (CRPC). This is due to androgen-independent signaling of the androgen receptor (AR) and consecutive androgen-independent downstream signaling [141]. Treatment options upon progression into CRPC include novel antiandrogens such as abiraterone [142] or enzalutamide [3] and chemotherapy regimens with docetaxel [143] and cabazitaxel [144]. Non-coding RNAs were reported to participate in PCa carcinogenesis $[14,145,146]$. Their potential involvement in 
the development of resistance to chemotherapy and ADT may pave the way for future therapeutic targets to overcome drug resistance in PCa.

\subsection{IncRNAs Promoting Drug Resistance in PCa}

\subsubsection{UCA1}

UCA1 plays a role in drug resistance across several cancer entities [147]. In PCa, UCA1 acts as a ceRNA and upregulation enhances tumor cell proliferation and progression [148,149]. Moreover, UCA1 may influence chemoresistance in PCa by sponging miR-204 (Figure 3B) [34]. Wang et al. [34] demonstrated the regulation of chemosensitivity via a UCA1/miR-204/Sirt1 pathway. Increased expression of UCA1 leads to the downregulation of miR-204 levels, resulting in elevated expression of Sirt1, which represents a target of miR-204 [34]. Sirt1 was previously demonstrated to enhance chemoresistance in PCa, corroborating this result [150]. Interestingly, elevated levels of UCA1 and Sirt1 and accordingly reduced levels of miR-204 were found in drug resistant PCa cancer cell lines, as compared to wildtype cell lines. Down- or upregulation of UCA1 or miR-204, respectively, improved docetaxel sensitivity and negatively influenced the expression of P-glycoprotein, a membrane pump that plays a major role in chemoresistance [34,151].

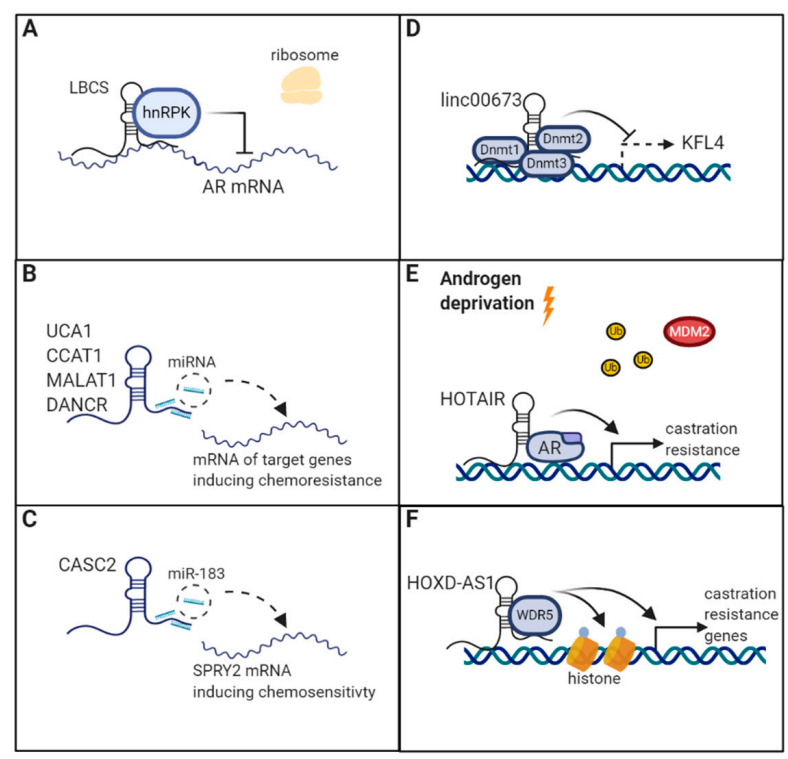

Figure 3. Examples of long non-coding RNAs (lncRNAs) and mechanisms of drug resistance in prostate cancer (PCa). (A) lncRNA low expression in bladder cancer stem cells (LBCS) recruits heterogeneous nuclear ribonucleoprotein $\mathrm{K}$ (hnRNPK) to the androgen receptor (AR) mRNA thereby preventing its translation. (B) lncRNAs sponge microRNAs and prevent them from binding to their targets. This leads to increased expression of the target proteins and induction of chemoresistance. (C) lncRNA cancer susceptibility candidate 2 (CASC2) acts as a competing endogenous RNA and sponges miR-183. This leads to increased expression of sprouty RTK signaling antagonist 2 (SPRY2) and restores resistance to chemotherapy. (D) lncRNA LINC00673 recruits DNMT1, DNMT22, and DNMT33 to the Krüppel-like factor 4 (KLF4) promoter and inhibits its transcription through increased methylation. This leads to increased chemoresistance. (E) lncRNA HOX transcript antisense RNA (HOTAIR) is increased under androgen deprivation and directly binds to the AR. This prevents AR ubiquitination and degradation by E3-ubiquitin-protein-ligase MDM2 and leads to AR signaling despite androgen deprivation therapy in castration resistant PCa. (F) lncRNA HOXD antisense RNA 1 (HOXD-AS1) recruits WD repeat-containing protein 5 (WDR5) to the promoter of chemo- and castration resistance-associated genes and mediates histone $\mathrm{H} 3$ lysine 4 tri-methylation (H3K4me3), thereby regulating the expression of target genes. (created with Biorender.com). 


\subsubsection{MALAT1}

lncRNA MALAT1 facilitates resistance to docetaxel in PCa through a MALAT1/miR-145-5p/ AKAP12 axis, as proposed by Xue et al. [36], who demonstrated MALAT1 and A-kinase anchoring protein 12 (AKAP12) competing for miR-145-5p. Consequently, overexpression of MALAT1 leads to increased docetaxel resistance in DU145 and PC3 PCa cell lines, both in in vitro and in vivo models. MALAT1 levels were also demonstrated to be significantly increased in docetaxel-resistant cells as compared to chemosensitive cells [36]. This corroborates previous results of altered MALAT1 expression in cancer $[152,153]$. Furthermore, MALAT1 was found to be involved in PCa invasion, proliferation and progression [154-156]. However, MALAT1 may also play a part in CRPC and in the pathogenesis of enzalutamide resistance [37], Enzalutamide is a second-generation AR antagonist that significantly improves outcomes after failure of primary ADT [3,157]. Wang et al. [37] found that MALAT1 mediated enzalutamide resistance, as it is a regulator of AR-v7 (also called AR3). AR-v7 is the most abundant splicing variant of AR and strongly associated to enzalutamide resistance in CRPC [158]. Mechanistically, overexpressed MALAT1 may influence enzalutamide resistance by forming a complex with the pre-mRNA splicing factor SF2 and thereby promoting its activity and positively regulating AR-v7 splicing. The suppression of MALAT1 as a potential therapeutic approach to overcome resistance to enzalutamide was shown in vitro and in vivo, respectively [37]. Interestingly, MALAT1 expression levels were higher in circulating tumor cells (CTC) of CRPC patients and analysis of the TCGA dataset revealed adverse prognosis of PCa patients with MALAT1 overexpression [37].

\subsubsection{LINC00673}

IncRNA LINC00673, which was found to be overexpressed in PCa, may affect drug resistance by recruiting DNA-methyltransferases (DNMT1, DNMT3a, and DNMT3b) to the KLF4 promoter. This results in enhanced methylation and epigenetic regulation of KLF4 expression (Figure 3D) [38]. KFL4 is involved in the regulation of many cellular functions such as cell growth, proliferation and differentiation, and may act as both a tumor suppressor and oncogene in a cellular context-dependent manner. In cancer, KLF4 function is frequently lost due to hypermethylation of CpG islands in the promotor region [159]. Suppression of LINC00673 led to improved chemosensitivity through increased KLF4 activity in both in vitro and in vivo experimental models and additionally reduced proliferation in PCa cell lines [38]. This is in line with results in gastric cancer, where epigenetic suppression of KLF4 through LINC00673 was associated with poor OS (HR $=2.989,95 \%$ CI $1.126-5.178, p=0.001)$ [160].

\subsubsection{LINC00518}

Increased levels of LINC00518 were found in both PCa cell lines and in PCa tumor tissues [39]. However, even higher expression levels were reported in chemoresistant PCa cell lines and PCa patients who were resistant to paclitaxel treatment and LINC00518 was related to poor outcome in a study by $\mathrm{He}$ et al. [39], that enrolled 45 patients. Missing uni- and multivariate analyses should be considered as a limitation. The authors proposed LINC00518 to enhance chemoresistance through a LINC00518/miR-216b-5p/GATA6 pathway. The sponging of mir-216-5p with LINC00518 prevents it from binding to its target, the transcription factor GATA6 [39]. GATA6 is involved in the pathogenesis and progression of several cancer entities [161]. Interestingly, miR-216b-5p additionally appears to play a role in drug resistance of other malignancies, such as melanoma and NSCLC, however, other target proteins were allocated to this effect $[100,162]$. Nonetheless, this supports the results by He et al. [39].

\subsubsection{CCAT1}

The colon cancer-associated transcript 1 (CCAT1) is an oncogenic lncRNA which has been widely reported to participate in cancer development and its utility as a biomarker in colorectal cancer has been demonstrated $[163,164]$. Accordingly, CCAT1 was demonstrated to be upregulated in PCa and was shown to enhance PCa proliferation, migration and invasion $[40,165,166]$. Only recently has 
the regulation of CCAT1 in metastatic CRPC via Vir-like m6A methyltransferase-associated protein (VIRMA)-dependent RNA-methylation become better understood [167]. In addition, Li et al. [40] identified CCAT1 as a potential novel target to influence drug resistance in PCa. Mechanistically, CCAT1 sequesters miR-24-3p and prevents it from targeting its downstream target fascin actin-bundling protein 1 (FSCN1), leading to increased FSCN1 expression levels and enhanced resistance to paclitaxel. Previous reports support the role of FSCN1 in chemoresistance $[168,169]$.

\subsubsection{DANCR}

The lncRNA differentiation antagonizing non-protein coding RNA (DANCR) affects chemoresistance of PCa cells by acting as a ceRNA, in this case for miR-34a-5p. miR-34a-5p was identified to directly bind to the 3'UTR of JAG1 (Jagged 1) mRNA leading to a reduction in JAGI expression levels [41]. Both, DANCR and JAG1 were found to be overexpressed in both PCa tissues of docetaxel-resistant patients and the docetaxel-resistant PCa cell lines DU-145 and PC-3. Silencing of DANCR could restore sensitivity to docetaxel treatment in vitro through the proposed DANCR/miR-34-5p/JAG1 axis, resulting in lower expression of P-glycoprotein and MRP1 and LRP1 proteins, which are associated with drug resistance in cancer [41]. JAG1 is part of the Notch signaling pathway and has been associated with disease progression and poor outcome in various cancer entities [170]. Interestingly, both JAG1 and miR-34-5p have already been demonstrated to influence drug resistance in other cancer entities [171,172], supporting the results of Ma et al. [41].

\subsubsection{HOXD-AS1/HAGLR}

The lncRNA HOXD antisense RNA 1 (HOXD-AS1), also called HAGLR (HOXD antisense growth-associated long non-coding RNA) is strongly related to cancer [173]. It is overexpressed in CRPC cell lines and its expression significantly associates with adverse prognostic clinico-pathological biomarkers such as Gleason-score, T-stage and nodal invasion [42]. In fact, increased HOXD-AS1 levels were significantly associated with poor PFS (HR 2.827, 95\%CI 1.297-6.161, $p=0.009$ ) in an analysis that included 309 PCa patients from the TCGA database [42]. Moreover, besides promoting cell proliferation, HOXD-AS1 enhances castration resistance to bicalutamide therapy as well as chemoresistance to paclitaxel in vitro and in vivo [42]. Mechanistically, HOXD-AS1 recruits WD repeat-containing protein 5 (WDR5), thereby mediating histone $\mathrm{H} 3$ lysine 4 tri-methylation (H3K4me3) (Figure 3F) [42,174]. This results in activated transcription of castration and chemoresistance, as well as proliferation-associated genes including PKL1, AURKA, FXM1, CDC25C, UVE2C, CCNA2, and CCNB1 [42]. Gu et al. [42] conclude that HOXD-AS1 may represent a future therapeutic target to reinstall castration- and chemosensitivity.

\subsubsection{FEZF1-AS1}

lncRNA FEZ family zinc finger 1-antisense RNA 1 (FEZF1-AS1) is an oncogenic lncRNA that is upregulated among various human malignancies. Its relation to tumor proliferation, migration and invasion, as well as its involvement in EMT through influencing tumorigenesis-associated pathways such as STATA3 and Wnt/ $\beta$-catenin, has been demonstrated [175]. In PCa, FEZF1-AS1 regulates resistance to paclitaxel via the FEZF1-AS1/miR-25-3p/ITGB8 pathway [43]. By sponging miR-25-3p, which directly targets ITGB8, FEZF1-AS1 prevents degradation of ITGB8 mRNA, resulting in preserved influence on chemoresistance as well as cell viability, EMT, and cell autophagy [43]. Wang et al. [43] demonstrated that silencing of FEZF1-AS1 could restore sensitivity to paclitaxel both in vitro and in vivo. ITGB8 has been shown to alter treatment resistance in several cancer entities, including ovarian and hepatic cancers and glioblastoma [176-178].

\subsubsection{HOTTIP}

The lncRNA HOXA distal transcript antisense RNA (HOTTIP) is strongly connected to cancer and has previously been reported to enhance tumor progression and chemoresistance [179]. Jiang et al. [44] were the first to investigate HOTTIP's involvement in PCa chemoresistance. As reported, suppression 
of HOTTIP resulted in increased cisplatin sensitivity in the PCa cell lines DU-145 and PC-3 by inhibiting $W n t / \beta$-catenin signaling [44]. This corroborates a number of previous studies that found HOTTIP to promote chemoresistance in numerous cancer entities [180-182], including osteosarcoma in which the regulation of $\mathrm{Wnt} / \beta$-catenin by HOTTIP was also described [182]. However, Jiang et al. [44] did not investigate if other potential effectors such as miRNAs or proteins are involved in the connection between HOTTIP and $W n t / \beta$-catenin regulation and moreover in vivo models are missing.

\subsubsection{PCGEM1}

PCGEM1 (prostate cancer gene expression marker 1) may regulate AR splicing and expression of AR3 (AR-v7) [45], and therefore participate in the development of enzalutamide resistance [158]. Mechanistically, in a recent study by Zhang et al. [45] PCGEM1 expression is promoted by androgen deprivation, leading to intracellular transfer in nuclear speckles. Furthermore, PCGEM1 regulates the activity of the splicing factors nhRNP A1 and U2AF65, which are competing for AR3 splicing. This results in suppression (mediated through nhRNP A1) or enhancement (mediated through U2AF65) of AR3 expression by alternative splicing. [45]. Nevertheless, available data is conflicting. Parolina et al. [183] report opposite results as PCGEM1 is downregulated under androgen deprivation and no nuclear speckles were formed. In conclusion, the role of PCGEM1 in PCa and AR-regulation is not yet conclusively defined, considering several studies showing inconsistent results [45,183-185].

\subsubsection{HOTAIR}

The lncRNA HOX transcript antisense RNA (HOTAIR) is upregulated in CRPC and may impact the development of enzalutamide resistance [46]. HOTAIR is suppressed by androgen through the AR protein and therefore upregulated under androgen deprivation and in CRPC. Moreover, increased HOTAIR expression was associated with shorter survival in a Kaplan-Meier analysis of two publicly available databases ( $p=0.04$, no uni- and multivariate models conducted) [46]. However, under androgen deprivation, HOTAIR expression increases and directly interacts with the AR protein at its $\mathrm{N}$-terminal end and subsequently prevents ubiquitination and consequent degradation by the E3-ubiquitin-protein-ligase MDM2. This preserves AR-signaling and transcriptional activity, thereby leading to castration resistance (Figure 3E). In a cell culture model of enzalutamide resistant cells, HOTAIR expression steadily increased over the time as cells were exposed to enzalutamide treatment, indicating its indispensable role in developing resistance to enzalutamide [46].

\subsubsection{LBCS}

The lncRNA LBCS was only recently described to exert regulatory function of AR-signaling in CRPC [47]. Specifically, LBCS expression is decreased in CRPC cell lines models and decreased expression was significantly and independently associated with shorter biochemical recurrence-free survival (BRFS) ( $\mathrm{HR}=0.447,95 \% \mathrm{CI}=0.235-0.967, p=0.040)$. It was demonstrated that induced overexpression of LBCS could reinstall sensitivity to androgen deprivation by recruiting hnRNPK binding directly to the AR mRNA and thereby limiting AR translation and activation [47] (Figure 3A). The mechanism of hnRNPK involvement in AR regulation has been reported previously [186].

\subsection{IncRNAs Enhancing Drug Sensitivity in PCa}

\section{CASC2}

Another lncRNA connected to docetaxel resistance in PCa cell lines is cancer susceptibility candidate 2 (CASC2) which has been associated with chemoresistance across various cancer entities, including gastric cancer [187], glioma [188], breast cancer [189], cervical cancer [190] and NSCLC [191]. In PCa, higher expression levels of CASC2 prevented miR-183 from binding to the 3'UTR of sprouty RTK signaling antagonist 2 (SPRY2) by acting as a ceRNA, thus preserving SPRY2 expression and inhibiting the downstream ERK signaling pathway, which is linked to chemoresistance [35,192] (Figure 3C). 
Activation of the ERK pathway in chemoresistant PCa cell lines was confirmed by a recent study investigating chemoresistance in PCa [40]. As a result, CASC2 promoted sensitivity to docetaxel in PCa cells [35].

\section{IncRNAs and Drug Resistance in Testicular Cancer}

TC accounts for $1 \%$ of cancers in males, which is approximately 55,000 patients per year worldwide [1,193]. Germ cell tumors are responsible for $95 \%$ of TC cases and can be subdivided into seminomas and non-seminomas [194].

Treatment strategies for localized TC include surgery (hemicastration or castration) as well as adjuvant chemotherapy depending on the presence of risk factors such as tumor extension and tumor marker decline (AFP, $\beta$ hCG, LDH) after surgery, which classifies patients in good, intermediate and poor risk groups [195]. As for systemic therapy options, standard-of-care in the adjuvant as well as first-line metastatic setting is cisplatin-based chemotherapy [196].

In TC, noncoding RNAs have already been investigated in regards to their involvement in pathogenesis and their potential utility as clinical biomarkers $[197,198]$. The fact that patients with TC show great response to cisplatin-based chemotherapy may be a reason why data on lncRNAs in the development of chemoresistance is extremely limited. In fact, to the best of our knowledge, there is only one study that investigated this subject [48].

H19

H19 is a well-investigated oncogenic lncRNA across various cancer types [199]. Regarding its involvement in chemoresistance in seminoma, Wei et al. [48] found H19 expression to be increased in the tissues of seminoma patients who were resistant to cisplatin-based chemotherapy, as well as in a cisplatin-resistant seminoma cell line. By acting as a ceRNA and thereby sponging miR-106-5p, which targets testis development related 1 (TDRG1), overexpression of H19 results in enhanced TDRG1 expression and reduced sensitivity to cisplatin treatment [48]. The authors proposed TDRG1, whose expression is exclusive in testis, to influence chemoresistance based on a previous work, which reported TDRG1 affecting resistance to cisplatin treatment in seminoma by regulating the PI3K/Akt/mTOR pathway [48,200,201]. Wei et al. [48] validated the promotion of chemoresistance by H19 in additional in vivo experiments, however, they only used one single cell line throughout their study and tissue samples of only 10 patients were used. Therefore, the results must be interpreted with caution and should only be considered hypothesis-generating until confirmed by further research. H19 was found to impact cisplatin resistance in other cancer entities [202-205], which is in line with and may support the results by Wei et al. [48].

\section{Conclusions}

In this review, we gave a comprehensive overview of lncRNAs and their involvement in drug resistance in cancers of the genitourinary system. Understanding the relation between lncRNAs and the biomarkers use and the development of drug and therapy resistance is crucial as lncRNAs may represent powerful therapeutic targets to overcome drug resistance and improve the outcome of cancer patients [206-209].

Author Contributions: Conceptualization, D.A.B., J.J., G.A.C.; writing—original draft preparation, D.A.B., J.J.; writing-review and editing, all authors.; visualization, D.A.B.; supervision, G.A.C.; funding acquisition, M.P., O.S., G.A.C.; All authors have read and agreed to the published version of the manuscript.

Funding: Calin is the Felix L. Haas Endowed Professor in Basic Science. Work in Calin's laboratory is supported by National Institutes of Health (NIH/NCATS) grant UH3TR00943-01 through the NIH Common Fund, Office of Strategic Coordination (OSC), the NCI grants 1R01 CA182905-01 and 1R01CA222007-01A1, an NIGMS 1R01GM122775-01 grant, a Team DOD (CA160445P1) grant, a Chronic Lymphocytic Leukemia Moonshot Flagship project, a CLL Global Research Foundation 2019 grant, a CLL Global Research Foundation 2020 grant, donor support through Jaffer Ajani and the Estate of C. G. Johnson, Jr. D.A.B. and J.J. were funded from the European Union's Horizon 2020 research and innovation programme under the Marie Skłodowska-Curie grant agreement No 824036. 
Conflicts of Interest: The authors declare no conflict of interest.

\section{References}

1. Ferlay, J.; Soerjomataram, I.; Dikshit, R.; Eser, S.; Mathers, C.; Rebelo, M.; Parkin, D.M.; Forman, D.; Bray, F. Cancer Incidence and Mortality Worldwide: Sources, Methods and Major Patterns in GLOBOCAN 2012. Int. J. Cancer 2015, 136, E359-E386. [CrossRef] [PubMed]

2. Suarez, C.; Puente, J.; Gallardo, E.; Mendez-Vidal, M.J.; Climent, M.A.; Leon, L.; Olmos, D.; Garcia del Muro, X.; Gonzalez-Billalabeitia, E.; Grande, E.; et al. New Advances in Genitourinary Cancer: Evidence Gathered in 2014. Cancer Metastasis Rev. 2015, 34, 443-464. [CrossRef] [PubMed]

3. Beer, T.M.; Armstrong, A.J.; Rathkopf, D.E.; Loriot, Y.; Sternberg, C.N.; Higano, C.S.; Iversen, P.; Bhattacharya, S.; Carles, J.; Chowdhury, S.; et al. Enzalutamide in Metastatic Prostate Cancer before Chemotherapy. N. Engl. J. Med. 2014, 371, 424-433. [CrossRef]

4. Bellmunt, J.; de Wit, R.; Vaughn, D.J.; Fradet, Y.; Lee, J.L.; Fong, L.; Vogelzang, N.J.; Climent, M.A.; Petrylak, D.P.; Choueiri, T.K.; et al. Pembrolizumab as Second-Line Therapy for Advanced Urothelial Carcinoma. N. Engl. J. Med. 2017, 376, 1015-1026. [CrossRef] [PubMed]

5. Motzer, R.J.; Tannir, N.M.; McDermott, D.F.; Aren Frontera, O.; Melichar, B.; Choueiri, T.K.; Plimack, E.R.; Barthelemy, P.; Porta, C.; George, S.; et al. Nivolumab Plus Ipilimumab Versus Sunitinib in Advanced Renal-Cell Carcinoma. N. Engl. J. Med. 2018, 378, 1277-1290. [CrossRef] [PubMed]

6. Garcia-Mayea, Y.; Mir, C.; Masson, F.; Paciucci, R.; LLeonart, M.E. Insights into New Mechanisms and Models of Cancer Stem Cell Multidrug Resistance. Semin. Cancer Biol. 2020, 60, 166-180. [CrossRef]

7. Seles, M.; Hutterer, G.C.; Fosselteder, J.; Svoboda, M.; Resel, M.; Barth, D.A.; Pichler, R.; Bauernhofer, T.; Zigeuner, R.E.; Pummer, K.; et al. Long Non-Coding RNA PANTR1 is Associated with Poor Prognosis and Influences Angiogenesis and Apoptosis in Clear-Cell Renal Cell Cancer. Cancers 2020, 12, 1200. [CrossRef]

8. Pichler, M.; Rodriguez-Aguayo, C.; Nam, S.Y.; Dragomir, M.P.; Bayraktar, R.; Anfossi, S.; Knutsen, E.; Ivan, C.; Fuentes-Mattei, E.; Lee, S.K.; et al. Therapeutic Potential of FLANC, a Novel Primate-Specific Long Non-Coding RNA in Colorectal Cancer. Gut 2020. [CrossRef]

9. Shah, M.Y.; Ferracin, M.; Pileczki, V.; Chen, B.; Redis, R.; Fabris, L.; Zhang, X.; Ivan, C.; Shimizu, M.; Rodriguez-Aguayo, C.; et al. Cancer-Associated rs6983267 SNP and its Accompanying Long Noncoding RNA CCAT2 Induce Myeloid Malignancies Via Unique SNP-Specific RNA Mutations. Genome Res. 2018, 28, 432-447. [CrossRef]

10. Fabbri, M.; Girnita, L.; Varani, G.; Calin, G.A. Decrypting Noncoding RNA Interactions, Structures, and Functional Networks. Genome Res. 2019, 29, 1377-1388. [CrossRef]

11. Rigoutsos, I.; Lee, S.K.; Nam, S.Y.; Anfossi, S.; Pasculli, B.; Pichler, M.; Jing, Y.; Rodriguez-Aguayo, C.; Telonis, A.G.; Rossi, S.; et al. N-BLR, a Primate-Specific Non-Coding Transcript Leads to Colorectal Cancer Invasion and Migration. Genome Biol. 2017, 18, 98. [CrossRef] [PubMed]

12. Ma, L.; Bajic, V.B.; Zhang, Z. On the Classification of Long Non-Coding RNAs. RNA Biol. 2013, 10, 925-933. [CrossRef] [PubMed]

13. Wang, K.; Chang, H. Molecular Mechanisms of Long Noncoding RNAs. Mol. Cell 2011, 43, $904-914$. [CrossRef] [PubMed]

14. Martens-Uzunova, E.S.; Bottcher, R.; Croce, C.M.; Jenster, G.; Visakorpi, T.; Calin, G.A. Long Noncoding RNA in Prostate, Bladder, and Kidney Cancer. Eur. Urol. 2014, 65, 1140-1151. [CrossRef]

15. Xu, Z.; Yang, F.; Wei, D.; Liu, B.; Chen, C.; Bao, Y.; Wu, Z.; Wu, D.; Tan, H.; Li, J.; et al. Long Noncoding RNA-SRLR Elicits Intrinsic Sorafenib Resistance Via Evoking IL-6/STAT3 Axis in Renal Cell Carcinoma. Oncogene 2017, 36, 1965-1977. [CrossRef]

16. Qu, L.; Ding, J.; Chen, C.; Wu, Z.J.; Liu, B.; Gao, Y.; Chen, W.; Liu, F.; Sun, W.; Li, X.F.; et al. ExosomeTransmitted lncARSR Promotes Sunitinib Resistance in Renal Cancer by Acting as a Competing Endogenous RNA. Cancer Cell. 2016, 29, 653-668. [CrossRef]

17. Song, E.L.; Xing, L.; Wang, L.; Song, W.T.; Li, D.B.; Wang, Y.; Gu, Y.W.; Liu, M.M.; Ni, W.J.; Zhang, P.; et al. LncRNA ADAMTS9-AS2 Inhibits Cell Proliferation and Decreases Chemoresistance in Clear Cell Renal Cell Carcinoma Via the miR-27a-3p/FOXO1 Axis. Aging Albany NY 2019, 11, 5705-5725. [CrossRef] 
18. Liu, F.; Chen, N.; Gong, Y.; Xiao, R.; Wang, W.; Pan, Z. The Long Non-Coding RNA NEAT1 Enhances Epithelial-to-Mesenchymal Transition and Chemoresistance Via the miR-34a/C-Met Axis in Renal Cell Carcinoma. Oncotarget 2017, 8, 62927-62938. [CrossRef]

19. Liu, L.; Pang, X.; Shang, W.; Xie, H.; Feng, Y.; Feng, G. Long Non-Coding RNA GAS5 Sensitizes Renal Cell Carcinoma to Sorafenib Via miR-21/SOX5 Pathway. Cell. Cycle 2019, 18, 257-263. [CrossRef]

20. Pan, J.; Li, X.; Wu, W.; Xue, M.; Hou, H.; Zhai, W.; Chen, W. Long Non-Coding RNA UCA1 Promotes Cisplatin/Gemcitabine Resistance through CREB Modulating miR-196a-5p in Bladder Cancer Cells. Cancer Lett. 2016, 382, 64-76. [CrossRef]

21. Fan, Y.; Shen, B.; Tan, M.; Mu, X.; Qin, Y.; Zhang, F.; Liu, Y. Long Non-Coding RNA UCA1 Increases Chemoresistance of Bladder Cancer Cells by Regulating Wnt Signaling. FEBS J. 2014, 281, 1750-1758. [CrossRef] [PubMed]

22. Wu, J.; Li, W.; Ning, J.; Yu, W.; Rao, T.; Cheng, F. Long Noncoding RNA UCA1 Targets miR-582-5p and Contributes to the Progression and Drug Resistance of Bladder Cancer Cells through ATG7-Mediated Autophagy Inhibition. Onco Targets Ther. 2019, 12, 495-508. [CrossRef] [PubMed]

23. Yu, G.; Zhou, H.; Yao, W.; Meng, L.; Lang, B. lncRNA TUG1 Promotes Cisplatin Resistance by Regulating CCND2 Via Epigenetically Silencing miR-194-5p in Bladder Cancer. Mol. Ther. Nucleic Acids 2019, 16, 257-271. [CrossRef] [PubMed]

24. Liu, Z.; Zhang, H. LncRNA Plasmacytoma Variant Translocation 1 is an Oncogene in Bladder Urothelial Carcinoma. Oncotarget 2017, 8, 64273-64282. [CrossRef] [PubMed]

25. An, Q.; Zhou, L.; Xu, N. Long Noncoding RNA FOXD2-AS1 Accelerates the Gemcitabine-Resistance of Bladder Cancer by Sponging miR-143. Biomed. Pharmacother. 2018, 103, 415-420. [CrossRef] [PubMed]

26. Li, Y.; Shi, B.; Dong, F.; Zhu, X.; Liu, B.; Liu, Y. Long Non-Coding RNA DLEU1 Promotes Cell Proliferation, Invasion, and Confers Cisplatin Resistance in Bladder Cancer by Regulating the miR-99b/HS3ST3B1 Axis. Front. Genet. 2019, 10, 280. [CrossRef] [PubMed]

27. Chen, J.; Li, Y.; Li, Z.; Cao, L. LncRNA MST1P2/miR-133b Axis Affects the Chemoresistance of Bladder Cancer to Cisplatin-Based Therapy Via Sirt1/p53 Signaling. J. Biochem. Mol. Toxicol. 2020, 34, e22452. [CrossRef]

28. Chen, X.; Liu, M.; Meng, F.; Sun, B.; Jin, X.; Jia, C. The Long Noncoding RNA HIF1A-AS2 Facilitates Cisplatin Resistance in Bladder Cancer. J. Cell. Biochem. 2019, 120, 243-252. [CrossRef]

29. Li, B.; Xie, D.; Zhang, H. Long Non-Coding RNA GHET1 Contributes to Chemotherapeutic Resistance to Gemcitabine in Bladder Cancer. Cancer Chemother. Pharmacol. 2019, 84, 187-194. [CrossRef]

30. Liu, P.; Li, X.; Cui, Y.; Chen, J.; Li, C.; Li, Q.; Li, H.; Zhang, X.; Zu, X. LncRNA-MALAT1 Mediates Cisplatin Resistance Via miR-101-3p/VEGF-C Pathway in Bladder Cancer. Acta Biochim. Biophys. Sin. Shanghai 2019, 51, 1148-1157. [CrossRef]

31. Zhuang, J.; Shen, L.; Yang, L.; Huang, X.; Lu, Q.; Cui, Y.; Zheng, X.; Zhao, X.; Zhang, D.; Huang, R.; et al. TGFbeta1 Promotes Gemcitabine Resistance through Regulating the LncRNA-LET/NF90/miR-145 Signaling Axis in Bladder Cancer. Theranostics 2017, 7, 3053-3067. [CrossRef] [PubMed]

32. Zhang, H.; Guo, Y.; Song, Y.; Shang, C. Long Noncoding RNA GAS5 Inhibits Malignant Proliferation and Chemotherapy Resistance to Doxorubicin in Bladder Transitional Cell Carcinoma. Cancer Chemother. Pharmacol. 2017, 79, 49-55. [CrossRef] [PubMed]

33. Chen, X.; Xie, R.; Gu, P.; Huang, M.; Han, J.; Dong, W.; Xie, W.; Wang, B.; He, W.; Zhong, G.; et al. Long Noncoding RNA LBCS Inhibits Self-Renewal and Chemoresistance of Bladder Cancer Stem Cells through Epigenetic Silencing of SOX2. Clin. Cancer Res. 2019, 25, 1389-1403. [CrossRef]

34. Wang, X.; Yang, B.; Ma, B. The UCA1/miR-204/Sirt1 Axis Modulates Docetaxel Sensitivity of Prostate Cancer Cells. Cancer Chemother. Pharmacol. 2016, 78, 1025-1031. [CrossRef] [PubMed]

35. Gao, W.; Lin, S.; Cheng, C.; Zhu, A.; Hu, Y.; Shi, Z.; Zhang, X.; Hong, Z. Long Non-Coding RNA CASC2 Regulates Sprouty2 Via Functioning as a Competing Endogenous RNA for miR-183 to Modulate the Sensitivity of Prostate Cancer Cells to Docetaxel. Arch. Biochem. Biophys. 2019, 665, 69-78. [CrossRef]

36. Xue, D.; Lu, H.; Xu, H.Y.; Zhou, C.X.; He, X.Z. Long Noncoding RNA MALAT1 Enhances the Docetaxel Resistance of Prostate Cancer Cells Via miR-145-5p-Mediated Regulation of AKAP12. J. Cell. Mol. Med. 2018, 22, 3223-3237. [CrossRef] [PubMed] 
37. Wang, R.; Sun, Y.; Li, L.; Niu, Y.; Lin, W.; Lin, C.; Antonarakis, E.S.; Luo, J.; Yeh, S.; Chang, C. Preclinical Study using Malat1 Small Interfering RNA Or Androgen Receptor Splicing Variant 7 Degradation Enhancer ASC-J9 $\left({ }^{\circledR}\right)$ to Suppress Enzalutamide-Resistant Prostate Cancer Progression. Eur. Urol. 2017, 72, 835-844. [CrossRef] [PubMed]

38. Jiang, Z.; Zhang, Y.; Chen, X.; Wu, P.; Chen, D. Long Non-Coding RNA LINC00673 Silencing Inhibits Proliferation and Drug Resistance of Prostate Cancer Cells Via Decreasing KLF4 Promoter Methylation. J. Cell. Mol. Med. 2020, 24, 1878-1892. [CrossRef]

39. He, J.; Sun, M.; Geng, H.; Tian, S. Long Non-Coding RNA Linc00518 Promotes Paclitaxel Resistance of the Human Prostate Cancer by Sequestering miR-216b-5p. Biol. Cell. 2019, 111, 39-50. [CrossRef]

40. Li, X.; Han, X.; Wei, P.; Yang, J.; Sun, J. Knockdown of lncRNA CCAT1 Enhances Sensitivity of Paclitaxel in Prostate Cancer Via Regulating miR-24-3p and FSCN1. Cancer. Biol. Ther. 2020, 21, 452-462. [CrossRef]

41. Ma, Y.; Fan, B.; Ren, Z.; Liu, B.; Wang, Y. Long Noncoding RNA DANCR Contributes to Docetaxel Resistance in Prostate Cancer through Targeting the miR-34a-5p/JAG1 Pathway. Onco Targets Ther. 2019, 12, 5485-5497. [CrossRef]

42. Gu, P.; Chen, X.; Xie, R.; Han, J.; Xie, W.; Wang, B.; Dong, W.; Chen, C.; Yang, M.; Jiang, J.; et al. IncRNA HOXD-AS1 Regulates Proliferation and Chemo-Resistance of Castration-Resistant Prostate Cancer via Recruiting WDR5. Mol. Ther. J. Am. Soc. Gene Ther. 2017, 25, 1959-1973. [CrossRef] [PubMed]

43. Wang, Z.H.; Wang, J.H.; Wang, K.Q.; Zhou, Y.; Wang, J. LncRNA FEZF1-AS1 Promoted Chemoresistance, Autophagy and Epithelial-Mesenchymal Transition (EMT) through Regulation of miR-25-3p/ITGB8 Axis in Prostate Cancer. Eur. Rev. Med. Pharmacol. Sci. 2020, 24, 2281-2293. [PubMed]

44. Jiang, H.; Xiong, W.; Chen, L.; Lv, Z.; Yang, C.; Li, Y. Knockdown of the Long Noncoding RNA HOTTIP Inhibits Cell Proliferation and Enhances Cell Sensitivity to Cisplatin by Suppressing the Wnt/Beta-Catenin Pathway in Prostate Cancer. J. Cell. Biochem. 2019, 120, 8965-8974. [CrossRef] [PubMed]

45. Zhang, Z.; Zhou, N.; Huang, J.; Ho, T.T.; Zhu, Z.; Qiu, Z.; Zhou, X.; Bai, C.; Wu, F.; Xu, M.; et al. Regulation of Androgen Receptor Splice Variant AR3 by PCGEM1. Oncotarget 2016, 7, 15481-15491. [CrossRef]

46. Zhang, A.; Zhao, J.C.; Kim, J.; Fong, K.W.; Yang, Y.A.; Chakravarti, D.; Mo, Y.Y.; Yu, J. LncRNA HOTAIR Enhances the Androgen-Receptor-Mediated Transcriptional Program and Drives Castration-Resistant Prostate Cancer. Cell. Rep. 2015, 13, 209-221. [CrossRef]

47. Gu, P.; Chen, X.; Xie, R.; Xie, W.; Huang, L.; Dong, W.; Han, J.; Liu, X.; Shen, J.; Huang, J.; et al. A Novel AR Translational Regulator lncRNA LBCS Inhibits Castration Resistance of Prostate Cancer. Mol. Cancer 2019, 18, 1-14. [CrossRef]

48. Wei, J.; Gan, Y.; Peng, D.; Jiang, X.; Kitazawa, R.; Xiang, Y.; Dai, Y.; Tang, Y.; Yang, J. Long Non-Coding RNA H19 Promotes TDRG1 Expression and Cisplatin Resistance by Sequestering miRNA-106b-5p in Seminoma. Cancer. Med. 2018, 7, 6247-6257. [CrossRef]

49. Znaor, A.; Lortet-Tieulent, J.; Laversanne, M.; Jemal, A.; Bray, F. International Variations and Trends in Renal Cell Carcinoma Incidence and Mortality. Eur. Urol. 2015, 67, 519-530. [CrossRef]

50. Rini, B.I.; Campbell, S.C.; Escudier, B. Renal Cell Carcinoma. Lancet 2009, 373, 1119-1132. [CrossRef]

51. Manini, C.; López, J.I. The Labyrinth of Renal Cell Carcinoma. Cancers 2020, 12, 521. [CrossRef] [PubMed]

52. Amato, R.J. Chemotherapy for Renal Cell Carcinoma. Semin. Oncol. 2000, 27, 177-186. [PubMed]

53. Negrier, S.; Perol, D.; Ravaud, A.; Chevreau, C.; Bay, J.O.; Delva, R.; Sevin, E.; Caty, A.; Escudier, B.; French Immunotherapy Intergroup. Medroxyprogesterone, Interferon Alfa-2a, Interleukin 2, Or Combination of both Cytokines in Patients with Metastatic Renal Carcinoma of Intermediate Prognosis: Results of a Randomized Controlled Trial. Cancer 2007, 110, 2468-2477. [CrossRef] [PubMed]

54. Escudier, B.; Eisen, T.; Stadler, W.M.; Szczylik, C.; Oudard, S.; Siebels, M.; Negrier, S.; Chevreau, C.; Solska, E.; Desai, A.A.; et al. Sorafenib in Advanced Clear-Cell Renal-Cell Carcinoma. N. Engl. J. Med. 2007, 356, 125-134. [CrossRef] [PubMed]

55. Motzer, R.J.; Hutson, T.E.; Tomczak, P.; Michaelson, M.D.; Bukowski, R.M.; Oudard, S.; Negrier, S.; Szczylik, C.; Pili, R.; Bjarnason, G.A.; et al. Overall Survival and Updated Results for Sunitinib Compared with Interferon Alfa in Patients with Metastatic Renal Cell Carcinoma. J. Clin. Oncol. 2009, 27, 3584-3590. [CrossRef]

56. Rini, B.I.; Plimack, E.R.; Stus, V.; Gafanov, R.; Hawkins, R.; Nosov, D.; Pouliot, F.; Alekseev, B.; Soulieres, D.; Melichar, B.; et al. Pembrolizumab Plus Axitinib Versus Sunitinib for Advanced Renal-Cell Carcinoma. N. Engl. J. Med. 2019, 380, 1116-1127. [CrossRef] 
57. Nunes-Xavier, C.E.; Angulo, J.C.; Pulido, R.; López, J.I. A Critical Insight into the Clinical Translation of PD-1/PD-L1 Blockade Therapy in Clear Cell Renal Cell Carcinoma. Curr. Urol. Rep. 2019, 20, 1. [CrossRef]

58. Turajlic, S.; Xu, H.; Litchfield, K.; Rowan, A.; Horswell, S.; Chambers, T.; O’Brien, T.; Lopez, J.I.; Watkins, T.B.K.; Nicol, D.; et al. Deterministic Evolutionary Trajectories Influence Primary Tumor Growth: TRACERx Renal. Cell 2018, 173, 595-610.e11. [CrossRef]

59. Turajlic, S.; Xu, H.; Litchfield, K.; Rowan, A.; Chambers, T.; Lopez, J.I.; Nicol, D.; O’Brien, T.; Larkin, J.; Horswell, S.; et al. Tracking Cancer Evolution Reveals Constrained Routes to Metastases: TRACERx Renal. Cell 2018, 173, 581-594.e12. [CrossRef]

60. Seles, M.; Hutterer, G.C.; Kiesslich, T.; Pummer, K.; Berindan-Neagoe, I.; Perakis, S.; Schwarzenbacher, D.; Stotz, M.; Gerger, A.; Pichler, M. Current Insights into Long Non-Coding RNAs in Renal Cell Carcinoma. Int. J. Mol. Sci. 2016, 17, 573. [CrossRef]

61. Zhou, Y.; Zhu, Y.; Xie, Y.; Ma, X. The Role of Long Non-Coding RNAs in Immunotherapy Resistance. Front. Oncol. 2019, 9, 1292. [CrossRef] [PubMed]

62. Smolle, M.A.; Prinz, F.; Calin, G.A.; Pichler, M. Current Concepts of Non-Coding RNA Regulation of Immune Checkpoints in Cancer. Mol. Aspects Med. 2019, 70, 117-126. [CrossRef] [PubMed]

63. Li, L.; Zhu, J.; Ye, F.; Duan, Z.; Zhou, J.; Huang, Z.; Wang, L. Upregulation of the lncRNA SRLR in Polycystic Ovary Syndrome Regulates Cell Apoptosis and IL-6 Expression. Cell Biochem. Funct. 2020. [CrossRef] [PubMed]

64. Xing, Q.; Li, R.; Xu, A.; Qin, Z.; Tang, J.; Zhang, L.; Tang, M.; Han, P.; Wang, W.; Qin, C.; et al. Genetic Variants in a Long Noncoding RNA Related to Sunitinib Resistance Predict Risk and Survival of Patients with Renal Cell Carcinoma. Cancer Med. 2019, 8, 2886-2896. [CrossRef] [PubMed]

65. Klec, C.; Prinz, F.; Pichler, M. Involvement of the Long Noncoding RNA NEAT1 in Carcinogenesis. Mol. Oncol. 2019, 13, 46-60. [CrossRef] [PubMed]

66. An, J.; Lv, W.; Zhang, Y. LncRNA NEAT1 Contributes to Paclitaxel Resistance of Ovarian Cancer Cells by Regulating ZEB1 Expression Via miR-194. Onco Targets Ther. 2017, 10, 5377-5390. [CrossRef] [PubMed]

67. Shin, V.Y.; Chen, J.; Cheuk, I.W.; Siu, M.T.; Ho, C.W.; Wang, X.; Jin, H.; Kwong, A. Long Non-Coding RNA NEAT1 Confers Oncogenic Role in Triple-Negative Breast Cancer through Modulating Chemoresistance and Cancer Stemness. Cell. Death Dis. 2019, 10. [CrossRef]

68. Hara, T.; Makino, T.; Yamasaki, M.; Tanaka, K.; Miyazaki, Y.; Takahashi, T.; Kurokawa, Y.; Nakajima, K.; Matsuura, N.; Mori, M.; et al. Effect of C-Met and CD44v6 Expression in Resistance to Chemotherapy in Esophageal Squamous Cell Carcinoma. Ann. Surg. Oncol. 2019, 26, 899-906. [CrossRef]

69. Sun, Z.Y.; Jian, Y.K.; Zhu, H.Y.; Li, B. IncRNAPVT1 Targets miR-152 to Enhance Chemoresistance of Osteosarcoma to Gemcitabine through Activating C-MET/PI3K/AKT Pathway. Pathol. Res. Pract. 2019, 215, 555-563. [CrossRef]

70. Pu, Y.; Zhao, F.; Li, Y.; Cui, M.; Wang, H.; Meng, X.; Cai, S. The miR-34a-5p Promotes the Multi-Chemoresistance of Osteosarcoma Via Repression of the AGTR1 Gene. BMC Cancer 2017, 17, 45. [CrossRef]

71. Yan, Y.; Xu, Z.; Chen, X.; Wang, X.; Zeng, S.; Zhao, Z.; Qian, L.; Li, Z.; Wei, J.; Huo, L.; et al. Novel Function of lncRNA ADAMTS9-AS2 in Promoting Temozolomide Resistance in Glioblastoma Via Upregulating the FUS/MDM2 Ubiquitination Axis. Front. Cell. Dev. Biol. 2019, 7, 217. [CrossRef] [PubMed]

72. Shi, Y.F.; Lu, H.; Wang, H.B. Downregulated lncRNA ADAMTS9-AS2 in Breast Cancer Enhances Tamoxifen Resistance by Activating microRNA-130a-5p. Eur. Rev. Med. Pharmacol. Sci. 2019, 23, 1563-1573. [PubMed]

73. Ma, C.; Shi, X.; Zhu, Q.; Li, Q.; Liu, Y.; Yao, Y.; Song, Y. The Growth Arrest-Specific Transcript 5 (GAS5): A Pivotal Tumor Suppressor Long Noncoding RNA in Human Cancers. Tumour Biol. 2016, 37, 1437-1444. [CrossRef] [PubMed]

74. Gao, Z.Q.; Wang, J.F.; Chen, D.H.; Ma, X.S.; Yang, W.; Zhe, T.; Dang, X.W. Long Non-Coding RNA GAS5 Antagonizes the Chemoresistance of Pancreatic Cancer Cells through Down-Regulation of miR-181c-5p. Biomed. Pharmacother. 2018, 97, 809-817. [CrossRef] [PubMed]

75. Chen, Z.; Pan, T.; Jiang, D.; Jin, L.; Geng, Y.; Feng, X.; Shen, A.; Zhang, L. The lncRNA-GAS5/miR-221-3p/DKK2 Axis Modulates ABCB1-Mediated Adriamycin Resistance of Breast Cancer Via the Wnt/Beta-Catenin Signaling Pathway. Mol. Ther. Nucleic Acids 2020, 19, 1434-1448. [CrossRef]

76. Chen, D.; Wang, R.; Yu, C.; Cao, F.; Zhang, X.; Yan, F.; Chen, L.; Zhu, H.; Yu, Z.; Feng, J. FOX-A1 Contributes to Acquisition of Chemoresistance in Human Lung Adenocarcinoma Via Transactivation of SOX5. Ebiomedicine 2019, 44, 150-161. [CrossRef] 
77. Dai, X.; Fang, M.; Li, S.; Yan, Y.; Zhong, Y.; Du, B. miR-21 is Involved in Transforming Growth Factor Beta1-Induced Chemoresistance and Invasion by Targeting PTEN in Breast Cancer. Oncol. Lett. 2017, 14, 6929-6936.

78. Richters, A.; Aben, K.K.H.; Kiemeney, L.A.L.M. The Global Burden of Urinary Bladder Cancer: An Update. World J. Urol. 2019, 38, 1895-1904. [CrossRef]

79. Mitra, A.P.; Lin, H.; Datar, R.H.; Cote, R.J. Molecular Biology of Bladder Cancer: Prognostic and Clinical Implications. Clin. Genitourin. Cancer 2006, 5, 67-77.

80. Knowles, M.A.; Hurst, C.D. Molecular Biology of Bladder Cancer: New Insights into Pathogenesis and Clinical Diversity. Nat. Rev. Cancer 2015, 15, 25-41. [CrossRef]

81. Sexton, W.J.; Wiegand, L.R.; Correa, J.J.; Politis, C.; Dickinson, S.I.; Kang, L.C. Bladder Cancer: A Review of Non-Muscle Invasive Disease. Cancer Control 2010, 17, 256-268. [CrossRef] [PubMed]

82. Babjuk, M.; Burger, M.; Zigeuner, R.; Shariat, S.F.; van Rhijn, B.W.; CompÃ@)rat, E.; Sylvester, R.J.; Kaasinen, E.; BÃ Ihle, A.; Palou Redorta, J.; et al. EAU Guidelines on Non-Muscle-Invasive Urothelial Carcinoma of the Bladder: Update 2013. Eur. Urol. 2013, 64, 639-653. [CrossRef] [PubMed]

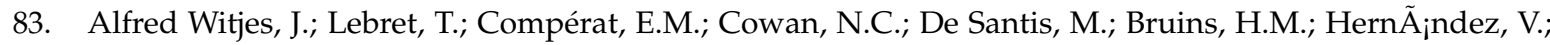
Espinós, E.L.; Dunn, J.; Rouanne, M.; et al. Updated 2016 EAU Guidelines on Muscle-Invasive and Metastatic Bladder Cancer. Eur. Urol. 2017, 71, 462-475. [CrossRef] [PubMed]

84. Loriot, Y.; Necchi, A.; Park, S.H.; Garcia-Donas, J.; Huddart, R.; Burgess, E.; Fleming, M.; Rezazadeh, A.; Mellado, B.; Varlamov, S.; et al. Erdafitinib in Locally Advanced Or Metastatic Urothelial Carcinoma. N. Engl. J. Med. 2019, 381, 338-348. [CrossRef]

85. Han, Y.; Liu, Y.; Gui, Y.; Cai, Z. Long Intergenic Non-Coding RNA TUG1 is Overexpressed in Urothelial Carcinoma of the Bladder. J. Surg. Oncol. 2013, 107, 555-559. [CrossRef]

86. Lebrun, L.; Milowich, D.; Le Mercier, M.; Allard, J.; Van Eycke, Y.R.; Roumeguere, T.; Decaestecker, C.; Salmon, I.; Rorive, S. UCA1 Overexpression is Associated with Less Aggressive Subtypes of Bladder Cancer. Oncol. Rep. 2018, 40, 2497-2506. [CrossRef]

87. Kukcinaviciute, E.; Jonusiene, V.; Sasnauskiene, A.; Dabkeviciene, D.; Eidenaite, E.; Laurinavicius, A. Significance of Notch and Wnt Signaling for Chemoresistance of Colorectal Cancer Cells HCT116. J. Cell. Biochem. 2018, 119, 5913-5920. [CrossRef]

88. Li, J.H.; Luo, N.; Zhong, M.Z.; Xiao, Z.Q.; Wang, J.X.; Yao, X.Y.; Peng, Y.; Cao, J. Inhibition of microRNA-196a might Reverse Cisplatin Resistance of A549/DDP Non-Small-Cell Lung Cancer Cell Line. Tumour Biol. 2016, 37, 2387-2394. [CrossRef]

89. Liu, Y.; Zhou, D.; Li, G.; Ming, X.; Tu, Y.; Tian, J.; Lu, H.; Yu, B. Long Non Coding RNA-UCA1 Contributes to Cardiomyocyte Apoptosis by Suppression of p27 Expression. Cell. Physiol. Biochem. 2015, 35, 1986-1998. [CrossRef]

90. Geng, J.; Klionsky, D.J. The Atg8 and Atg12 Ubiquitin-Like Conjugation Systems in Macroautophagy. 'Protein Modifications: Beyond the Usual Suspects' Review Series. EMBO Rep. 2008, 9, 859-864. [CrossRef]

91. Sui, X.; Chen, R.; Wang, Z.; Huang, Z.; Kong, N.; Zhang, M.; Han, W.; Lou, F.; Yang, J.; Zhang, Q.; et al. Autophagy and Chemotherapy Resistance: A Promising Therapeutic Target for Cancer Treatment. Cell. Death Dis. 2013, 4, e838. [CrossRef] [PubMed]

92. Young, T.L.; Matsuda, T.; Cepko, C.L. The Noncoding RNA Taurine Upregulated Gene 1 is Required for Differentiation of the Murine Retina. Curr. Biol. 2005, 15, 501-512. [CrossRef] [PubMed]

93. Sun, J.; Ding, C.; Yang, Z.; Liu, T.; Zhang, X.; Zhao, C.; Wang, J. The Long Non-Coding RNA TUG1 Indicates a Poor Prognosis for Colorectal Cancer and Promotes Metastasis by Affecting Epithelial-Mesenchymal Transition. J. Transl. Med. 2016, 14, 42. [CrossRef] [PubMed]

94. Zhang, E.; He, X.; Yin, D.; Han, L.; Qiu, M.; Xu, T.; Xia, R.; Xu, L.; Yin, R.; De, W. Increased Expression of Long Noncoding RNA TUG1 Predicts a Poor Prognosis of Gastric Cancer and Regulates Cell Proliferation by Epigenetically Silencing of p57. Cell. Death Dis. 2016, 7, e2109. [CrossRef] [PubMed]

95. Zhang, E.B.; Yin, D.D.; Sun, M.; Kong, R.; Liu, X.H.; You, L.H.; Han, L.; Xia, R.; Wang, K.M.; Yang, J.S.; et al. P53-Regulated Long Non-Coding RNA TUG1 Affects Cell Proliferation in Human Non-Small Cell Lung Cancer, Partly through Epigenetically Regulating HOXB7 Expression. Cell. Death Dis. 2014, 5, e1243. [CrossRef] 
96. Huang, M.D.; Chen, W.M.; Qi, F.Z.; Sun, M.; Xu, T.P.; Ma, P.; Shu, Y.Q. Long Non-Coding RNA TUG1 is Up-Regulated in Hepatocellular Carcinoma and Promotes Cell Growth and Apoptosis by Epigenetically Silencing of KLF2. Mol. Cancer. 2015, 14, 165. [CrossRef]

97. Iliev, R.; Kleinova, R.; Juracek, J.; Dolezel, J.; Ozanova, Z.; Fedorko, M.; Pacik, D.; Svoboda, M.; Stanik, M.; Slaby, O. Overexpression of Long Non-Coding RNA TUG1 Predicts Poor Prognosis and Promotes Cancer Cell Proliferation and Migration in High-Grade Muscle-Invasive Bladder Cancer. Tumour Biol. 2016, 37, 13385-13390. [CrossRef]

98. Shen, C.J.; Cheng, Y.M.; Wang, C.L. LncRNA PVT1 Epigenetically Silences miR-195 and Modulates EMT and Chemoresistance in Cervical Cancer Cells. J. Drug Target. 2017, 25, 637-644. [CrossRef]

99. Zhang, X.W.; Bu, P.; Liu, L.; Zhang, X.Z.; Li, J. Overexpression of Long Non-Coding RNA PVT1 in Gastric Cancer Cells Promotes the Development of Multidrug Resistance. Biochem. Biophys. Res. Commun. 2015, 462, 227-232. [CrossRef]

100. Chen, L.; Han, X.; Hu, Z.; Chen, L. The PVT1/miR-216b/Beclin-1 Regulates Cisplatin Sensitivity of NSCLC Cells Via Modulating Autophagy and Apoptosis. Cancer Chemother. Pharmacol. 2019, 83, 921-931. [CrossRef]

101. Su, F.; He, W.; Chen, C.; Liu, M.; Liu, H.; Xue, F.; Bi, J.; Xu, D.; Zhao, Y.; Huang, J.; et al. The Long Non-Coding RNA FOXD2-AS1 Promotes Bladder Cancer Progression and Recurrence through a Positive Feedback Loop with Akt and E2F1. Cell. Death Dis. 2018, 9, 233-239. [CrossRef] [PubMed]

102. Liu, X.; Yao, D.; Liu, C.; Cao, Y.; Yang, Q.; Sun, Z.; Liu, D. Overexpression of ABCC3 Promotes Cell Proliferation, Drug Resistance, and Aerobic Glycolysis and is Associated with Poor Prognosis in Urinary Bladder Cancer Patients. Tumour Biol. 2016, 37, 8367-8374. [CrossRef] [PubMed]

103. Bullrich, F.; Fujii, H.; Calin, G.; Mabuchi, H.; Negrini, M.; Pekarsky, Y.; Rassenti, L.; Alder, H.; Reed, J.C.; Keating, M.J.; et al. Characterization of the 13q14 Tumor Suppressor Locus in CLL: Identification of ALT1, an Alternative Splice Variant of the LEU2 Gene. Cancer Res. 2001, 61, 6640-6648. [PubMed]

104. Calin, G.A.; Croce, C.M. Chronic Lymphocytic Leukemia: Interplay between Noncoding RNAs and Protein-Coding Genes. Blood 2009, 114, 4761-4770. [CrossRef]

105. Liu, Y.; Corcoran, M.; Rasool, O.; Ivanova, G.; Ibbotson, R.; Grandér, D.; Iyengar, A.; Baranova, A.; Kashuba, V.; Merup, M.; et al. Cloning of Two Candidate Tumor Suppressor Genes within a $10 \mathrm{~Kb}$ Region on Chromosome 13q14, Frequently Deleted in Chronic Lymphocytic Leukemia. Oncogene 1997, 15, 2463-2473. [CrossRef]

106. Calin, G.A.; Dumitru, C.D.; Shimizu, M.; Bichi, R.; Zupo, S.; Noch, E.; Aldler, H.; Rattan, S.; Keating, M.; Rai, K.; et al. Frequent Deletions and Down-Regulation of Micro- RNA Genes miR15 and miR16 at 13q14 in Chronic Lymphocytic Leukemia. Proc. Natl. Acad. Sci. USA. 2002, 99, 15524-15529. [CrossRef]

107. Ciccone, M.; Calin, G.A. MicroRNAs in Chronic Lymphocytic Leukemia: An Old Disease with New Genetic Insights. Microrna 2016, 5, 106-112. [CrossRef]

108. Van Roosbroeck, K.; Calin, G.A. MicroRNAs in Chronic Lymphocytic Leukemia: Miracle or miRage for Prognosis and Targeted Therapies? Semin. Oncol. 2016, 43, 209-214. [CrossRef]

109. Van Roosbroeck, K.; Bayraktar, R.; Calin, S.; Bloehdorn, J.; Dragomir, M.P.; Okubo, K.; Bertilaccio, M.T.S.; Zupo, S.; You, M.J.; Gaidano, G.; et al. The Involvement of microRNA in the Pathogenesis of Richter Syndrome. Haematologica 2019, 104, 1004-1015. [CrossRef]

110. Lee, S.; Luo, W.; Shah, T.; Yin, C.; O'Connell, T.; Chung, T.H.; Perkins, S.L.; Miles, R.R.; Ayello, J.; Morris, E.; et al. The Effects of DLEU1 Gene Expression in Burkitt Lymphoma (BL): Potential Mechanism of Chemoimmunotherapy Resistance in BL. Oncotarget 2017, 8, 27839-27853. [CrossRef]

111. Liu, C.; Tian, X.; Zhang, J.; Jiang, L. Long Non-Coding RNA DLEU1 Promotes Proliferation and Invasion by Interacting with miR-381 and Enhancing HOXA13 Expression in Cervical Cancer. Front. Genet. 2018, 9, 629. [CrossRef] [PubMed]

112. Liu, T.; Han, Z.; Li, H.; Zhu, Y.; Sun, Z.; Zhu, A. LncRNA DLEU1 Contributes to Colorectal Cancer Progression Via Activation of KPNA3. Mol. Cancer 2018, 17, 118. [CrossRef] [PubMed]

113. Zhang, S.; Guan, Y.; Liu, X.; Ju, M.; Zhang, Q. Long Non-Coding RNA DLEU1 Exerts an Oncogenic Function in Non-Small Cell Lung Cancer. Biomed. Pharmacother. 2019, 109, 985-990. [CrossRef] [PubMed]

114. Li, W.; Chang, J.; Wang, S.; Liu, X.; Peng, J.; Huang, D.; Sun, M.; Chen, Z.; Zhang, W.; Guo, W.; et al. miRNA-99b-5p Suppresses Liver Metastasis of Colorectal Cancer by Down-Regulating mTOR. Oncotarget 2015, 6, 24448-24462. [CrossRef] 
115. Kang, J.; Lee, S.Y.; Lee, S.Y.; Kim, Y.J.; Park, J.Y.; Kwon, S.J.; Na, M.J.; Lee, E.J.; Jeon, H.S.; Son, J.W. microRNA-99b Acts as a Tumor Suppressor in Non-Small Cell Lung Cancer by Directly Targeting Fibroblast Growth Factor Receptor 3. Exp. Ther. Med. 2012, 3, 149-153. [CrossRef]

116. Van Rhijn, B.W.; Lurkin, I.; Radvanyi, F.; Kirkels, W.J.; van der Kwast, T.H.; Zwarthoff, E.C. The Fibroblast Growth Factor Receptor 3 (FGFR3) Mutation is a Strong Indicator of Superficial Bladder Cancer with Low Recurrence Rate. Cancer Res. 2001, 61, 1265-1268.

117. Song, K.; Li, Q.; Jiang, Z.Z.; Guo, C.W.; Li, P. Heparan Sulfate D-Glucosaminyl 3-O-Sulfotransferase-3B1, a Novel Epithelial-Mesenchymal Transition Inducer in Pancreatic Cancer. Cancer. Biol. Ther. 2011, 12, 388-398. [CrossRef]

118. Chen, S.; Jiao, J.W.; Sun, K.X.; Zong, Z.H.; Zhao, Y. MicroRNA-133b Targets Glutathione S-Transferase Ï€ Expression to Increase Ovarian Cancer Cell Sensitivity to Chemotherapy Drugs. Drug Des. Dev. Ther. 2015, 9, 5225-5235.

119. Lv, L.; Li, Q.; Chen, S.; Zhang, X.; Tao, X.; Tang, X.; Wang, S.; Che, G.; Yu, Y.; He, L. miR-133b Suppresses Colorectal Cancer Cell Stemness and Chemoresistance by Targeting Methyltransferase DOT1L. Exp. Cell Res. 2019, 385, 111597. [CrossRef]

120. Zou, Y.; Yang, J.; Wu, J.; Luo, C.; Huang, Y. miR-133b Induces Chemoresistance of Osteosarcoma Cells to Cisplatin Treatment by Promoting Cell Death, Migration and Invasion. Oncol. Lett. 2018, 15, 1097-1102. [CrossRef]

121. Vaziri, H.; Dessain, S.K.; Ng Eaton, E.; Imai, S.I.; Frye, R.A.; Pandita, T.K.; Guarente, L.; Weinberg, R.A. hSIR2(SIRT1) Functions as an NAD-Dependent p53 Deacetylase. Cell 2001, 107, 149-159. [CrossRef]

122. Bertozzi, D.; Iurlaro, R.; Sordet, O.; Marinello, J.; Zaffaroni, N.; Capranico, G. Characterization of Novel Antisense HIF-1alpha Transcripts in Human Cancers. Cell. Cycle 2011, 10, 3189-3197. [CrossRef] [PubMed]

123. Chen, M.; Zhuang, C.; Liu, Y.; Li, J.; Dai, F.; Xia, M.; Zhan, Y.; Lin, J.; Chen, Z.; He, A.; et al. TetracyclineInducible shRNA Targeting Antisense Long Non-Coding RNA HIF1A-AS2 Represses the Malignant Phenotypes of Bladder Cancer. Cancer Lett. 2016, 376, 155-164. [CrossRef] [PubMed]

124. Mineo, M.; Ricklefs, F.; Rooj, A.K.; Lyons, S.M.; Ivanov, P.; Ansari, K.I.; Nakano, I.; Chiocca, E.A.; Godlewski, J.; Bronisz, A. The Long Non-Coding RNA HIF1A-AS2 Facilitates the Maintenance of Mesenchymal Glioblastoma Stem-Like Cells in Hypoxic Niches. Cell Rep. 2016, 15, 2500-2509. [CrossRef] [PubMed]

125. Li, L.J.; Zhu, J.L.; Bao, W.S.; Chen, D.K.; Huang, W.W.; Weng, Z.L. Long Noncoding RNA GHET1 Promotes the Development of Bladder Cancer. Int. J. Clin. Exp. Pathol. 2014, 7, 7196-7205. [PubMed]

126. Li, X.; Wang, H.; Wang, J.; Chen, Y.; Yin, X.; Shi, G.; Li, H.; Hu, Z.; Liang, X. Emodin Enhances Cisplatin-Induced Cytotoxicity in Human Bladder Cancer Cells through ROS Elevation and MRP1 Downregulation. BMC Cancer 2016, 16, 578. [CrossRef]

127. Cao, W.; Liu, B.; Ma, H. Long Non-Coding RNA GHET1 Promotes Viability, Migration and Invasion of Glioma Cell Line U251 by Down-Regulation of miR-216a. Eur. Rev. Med. Pharmacol. Sci. 2019, 23, 1591-1599.

128. Hu, Z.; Lin, Y.; Chen, H.; Mao, Y.; Wu, J.; Zhu, Y.; Xu, X.; Xu, X.; Li, S.; Zheng, X.; et al. MicroRNA-101 Suppresses Motility of Bladder Cancer Cells by Targeting C-Met. Biochem. Biophys. Res. Commun. 2013, 435, 82-87. [CrossRef]

129. Zhu, H.; Yun, F.; Shi, X.; Wang, D. VEGF-C Inhibition Reverses Resistance of Bladder Cancer Cells to Cisplatin Via Upregulating Maspin. Mol. Med. Rep. 2015, 12, 3163-3169. [CrossRef]

130. Li, B.; Xie, D.; Zhang, H. MicroRNA-101-3p Advances Cisplatin Sensitivity in Bladder Urothelial Carcinoma through Targeted Silencing EZH2. J. Cancer 2019, 10, 2628-2634. [CrossRef]

131. Zhang, W.; Xiong, Z.; Wei, T.; Li, Q.; Tan, Y.; Ling, L.; Feng, X. Nuclear Factor 90 Promotes Angiogenesis by Regulating HIF-1 $\hat{\mathrm{I}} \pm$ /VEGF-A Expression through the PI3K/Akt Signaling Pathway in Human Cervical Cancer. Cell. Death Dis. 2018, 9, 276. [CrossRef]

132. Sakamoto, S.; Aoki, K.; Higuchi, T.; Todaka, H.; Morisawa, K.; Tamaki, N.; Hatano, E.; Fukushima, A.; Taniguchi, T.; Agata, Y. The NF90-NF45 Complex Functions as a Negative Regulator in the microRNA Processing Pathway. Mol. Cell. Biol. 2009, 29, 3754-3769. [CrossRef] [PubMed]

133. Davis-Dusenbery, B.; Chan, M.C.; Reno, K.E.; Weisman, A.S.; Layne, M.D.; Lagna, G.; Hata, A. Down-Regulation of Kruppel-Like Factor-4 (KLF4) by microRNA-143/145 is Critical for Modulation of Vascular Smooth Muscle Cell Phenotype by Transforming Growth Factor-Beta and Bone Morphogenetic Protein 4. J. Biol. Chem. 2011, 286, 28097-28110. [CrossRef] [PubMed] 
134. Wang, Y.; Song, Q.; Huang, X.; Chen, Z.; Zhang, F.; Wang, K.; Huang, G.; Shen, H. Long Noncoding RNA GAS5 Promotes Apoptosis in Primary Nucleus Pulposus Cells Derived from the Human Intervertebral Disc Via Bclâ€'2 Downregulation and Caspaseâ€’3 Upregulation. Mol. Med. Rep. 2019, 19, 2164-2172. [PubMed]

135. Chen, X.; Gu, P.; Xie, R.; Han, J.; Liu, H.; Wang, B.; Xie, W.; Xie, W.; Zhong, G.; Chen, C.; et al. Heterogeneous Nuclear Ribonucleoprotein $\mathrm{K}$ is Associated with Poor Prognosis and Regulates Proliferation and Apoptosis in Bladder Cancer. J. Cell. Mol. Med. 2017, 21, 1266-1279. [CrossRef] [PubMed]

136. Juan, A.H.; Derfoul, A.; Feng, X.; Ryall, J.G.; Dell'Orso, S.; Pasut, A.; Zare, H.; Simone, J.M.; Rudnicki, M.A.; Sartorelli, V. Polycomb EZH2 Controls Self-Renewal and Safeguards the Transcriptional Identity of Skeletal Muscle Stem Cells. Genes Dev. 2011, 25, 789-794. [CrossRef] [PubMed]

137. Zhu, F.; Qian, W.; Zhang, H.; Liang, Y.; Wu, M.; Zhang, Y.; Zhang, X.; Gao, Q.; Li, Y. SOX2 is a Marker for Stem-Like Tumor Cells in Bladder Cancer. Stem Cell Rep. 2017, 9, 429-437. [CrossRef]

138. Siegel, R.L.; Miller, K.D.; Jemal, A. Cancer Statistics, 2019. CA Cancer. J. Clin. 2019, 69, 7-34.

139. Mosillo, C.; Iacovelli, R.; Ciccarese, C.; Fantinel, E.; Bimbatti, D.; Brunelli, M.; Bisogno, I.; Kinspergher, S.; Buttigliero, C.; Tucci, M.; et al. De Novo Metastatic Castration Sensitive Prostate Cancer: State of Art and Future Perspectives. Cancer Treat. Rev. 2018, 70, 67-74. [CrossRef]

140. Pagliarulo, V.; Bracarda, S.; Eisenberger, M.A.; Mottet, N.; Schroder, F.H.; Sternberg, C.N.; Studer, U.E. Contemporary Role of Androgen Deprivation Therapy for Prostate Cancer. Eur. Urol. 2012, 61, 11-25. [CrossRef]

141. Mansinho, A.; Macedo, D.; Fernandes, I.; Costa, L. Castration-Resistant Prostate Cancer: Mechanisms, Targets and Treatment. Adv. Exp. Med. Biol. 2018, 1096, 117-133. [PubMed]

142. Ryan, C.J.; Smith, M.R.; de Bono, J.S.; Molina, A.; Logothetis, C.J.; de Souza, P.; Fizazi, K.; Mainwaring, P.; Piulats, J.M.; Ng, S.; et al. Abiraterone in Metastatic Prostate Cancer without Previous Chemotherapy. N. Engl. J. Med. 2013, 368, 138-148. [CrossRef] [PubMed]

143. Petrylak, D.P.; Tangen, C.M.; Hussain, M.H.; Lara, P.N., Jr.; Jones, J.A.; Taplin, M.E.; Burch, P.A.; Berry, D.; Moinpour, C.; Kohli, M.; et al. Docetaxel and Estramustine Compared with Mitoxantrone and Prednisone for Advanced Refractory Prostate Cancer. N. Engl. J. Med. 2004, 351, 1513-1520. [CrossRef] [PubMed]

144. De Wit, R.; de Bono, J.; Sternberg, C.N.; Fizazi, K.; Tombal, B.; Wulfing, C.; Kramer, G.; Eymard, J.C.; Bamias, A.; Carles, J.; et al. Cabazitaxel Versus Abiraterone Or Enzalutamide in Metastatic Prostate Cancer. N. Engl. J. Med. 2019, 381, 2506-2518. [CrossRef] [PubMed]

145. Fabris, L.; Ceder, Y.; Chinnaiyan, A.M.; Jenster, G.W.; Sorensen, K.D.; Tomlins, S.; Visakorpi, T.; Calin, G.A. The Potential of MicroRNAs as Prostate Cancer Biomarkers. Eur. Urol. 2016, 70, 312-322. [CrossRef] [PubMed]

146. Salameh, A.; Lee, A.K.; CardÃ3-Vila, M.; Nunes, D.N.; Efstathiou, E.; Staquicini, F.I.; Dobroff, A.S.; MarchiÃ2, S.; Navone, N.M.; Hosoya, H.; et al. PRUNE2 is a Human Prostate Cancer Suppressor Regulated by the Intronic Long Noncoding RNA PCA3. Proc. Natl. Acad. Sci. USA 2015, 112, 8403-8408. [CrossRef]

147. Wang, H.; Guan, Z.; He, K.; Qian, J.; Cao, J.; Teng, L. LncRNA UCA1 in Anti-Cancer Drug Resistance. Oncotarget 2017, 8, 64638-64650. [CrossRef]

148. He, C.; Lu, X.; Yang, F.; Qin, L.; Guo, Z.; Sun, Y.; Wu, J. LncRNA UCA1 Acts as a Sponge of miR-204 to Up-Regulate CXCR4 Expression and Promote Prostate Cancer Progression. Biosci. Rep. 2019, 39. [CrossRef]

149. Yu, Y.; Gao, F.; He, Q.; Li, G.; Ding, G. IncRNA UCA1 Functions as a ceRNA to Promote Prostate Cancer Progression Via Sponging miR143. Mol. Ther. Nucleic Acids 2020, 19, 751-758. [CrossRef]

150. Kojima, K.; Ohhashi, R.; Fujita, Y.; Hamada, N.; Akao, Y.; Nozawa, Y.; Deguchi, T.; Ito, M. A Role for SIRT1 in Cell Growth and Chemoresistance in Prostate Cancer PC3 and DU145 Cells. Biochem. Biophys. Res. Commun. 2008, 373, 423-428. [CrossRef]

151. Robey, R.W.; Pluchino, K.M.; Hall, M.D.; Fojo, A.T.; Bates, S.E.; Gottesman, M.M. Revisiting the Role of ABC Transporters in Multidrug-Resistant Cancer. Nat. Rev. Cancer. 2018, 18, 452-464. [CrossRef] [PubMed]

152. Lee, N.K.; Lee, J.H.; Ivan, C.; Ling, H.; Zhang, X.; Park, C.H.; Calin, G.A.; Lee, S.K. MALAT1 Promoted Invasiveness of Gastric Adenocarcinoma. BMC Cancer 2017, 17, 46. [CrossRef]

153. Smolle, M.A.; Bauernhofer, T.; Pummer, K.; Calin, G.A.; Pichler, M. Current Insights into Long Non-Coding RNAs (LncRNAs) in Prostate Cancer. Int. J. Mol. Sci. 2017, 18, 473. [CrossRef] [PubMed]

154. Hao, T.; Wang, Z.; Yang, J.; Zhang, Y.; Shang, Y.; Sun, J. MALAT1 Knockdown Inhibits Prostate Cancer Progression by Regulating miR-140/BIRC6 Axis. Biomed. Pharmacother. 2020, 123, 109666. [CrossRef] [PubMed] 
155. Wang, D.; Ding, L.; Wang, L.; Zhao, Y.; Sun, Z.; Karnes, R.J.; Zhang, J.; Huang, H. LncRNA MALAT1 Enhances Oncogenic Activities of EZH2 in Castration-Resistant Prostate Cancer. Oncotarget 2015, 6, 41045-41055. [CrossRef] [PubMed]

156. Dai, X.; Liang, Z.; Liu, L.; Guo, K.; Xu, S.; Wang, H. Silencing of MALAT1 Inhibits Migration and Invasion by Sponging miR13p in Prostate Cancer Cells. Mol. Med. Rep. 2019, 20, 3499-3508.

157. Hussain, M.; Fizazi, K.; Saad, F.; Rathenborg, P.; Shore, N.; Ferreira, U.; Ivashchenko, P.; Demirhan, E.; Modelska, K.; Phung, D.; et al. Enzalutamide in Men with Nonmetastatic, Castration-Resistant Prostate Cancer. N. Engl. J. Med. 2018, 378, 2465-2474. [CrossRef]

158. Antonarakis, E.S.; Lu, C.; Wang, H.; Luber, B.; Nakazawa, M.; Roeser, J.C.; Chen, Y.; Mohammad, T.A.; Chen, Y.; Fedor, H.L.; et al. AR-V7 and Resistance to Enzalutamide and Abiraterone in Prostate Cancer. N. Engl. J. Med. 2014, 371, 1028-1038. [CrossRef]

159. Ghaleb, A.M.; Yang, V.W. Kruppel-Like Factor 4 (KLF4): What we Currently Know. Gene 2017, 611, $27-37$. [CrossRef]

160. Ba, M.C.; Long, H.; Cui, S.Z.; Gong, Y.F.; Yan, Z.F.; Wu, Y.B.; Tu, Y.N. Long Noncoding RNA LINC00673 Epigenetically Suppresses KLF4 by Interacting with EZH2 and DNMT1 in Gastric Cancer. Oncotarget 2017, 8, 95542-95553. [CrossRef]

161. Sun, Z.; Yan, B. Multiple Roles and Regulatory Mechanisms of the Transcription Factor GATA6 in Human Cancers. Clin. Genet. 2020, 97, 64-72. [CrossRef] [PubMed]

162. Luo, M.; Wu, L.; Zhang, K.; Wang, H.; Wu, S.; O'Connell, D.; Gao, T.; Zhong, H.; Yang, Y. miR-216b Enhances the Efficacy of Vemurafenib by Targeting Beclin-1, UVRAG and ATG5 in Melanoma. Cell Signal. 2018, 42, 30-43. [CrossRef] [PubMed]

163. Ghafouri-Fard, S.; Taheri, M. Colon Cancer-Associated Transcripts 1 and 2: Roles and Functions in Human Cancers. J. Cell. Physiol. 2019, 234, 14581-14600. [CrossRef] [PubMed]

164. Ozawa, T.; Matsuyama, T.; Toiyama, Y.; Takahashi, N.; Ishikawa, T.; Uetake, H.; Yamada, Y.; Kusunoki, M.; Calin, G.; Goel, A. CCAT1 and CCAT2 Long Noncoding RNAs, Located within the 8q.24.21 'Gene Desert', Serve as Important Prognostic Biomarkers in Colorectal Cancer. Ann. Oncol. 2017, 28, 1882-1888. [CrossRef] [PubMed]

165. Chen, H.; He, Y.; Hou, Y.S.; Chen, D.Q.; He, S.L.; Cao, Y.F.; Wu, X.M. Long Non-Coding RNA CCAT1 Promotes the Migration and Invasion of Prostate Cancer PC-3 Cells. Eur. Rev. Med. Pharmacol. Sci. 2018, 22, 2991-2996. [PubMed]

166. You, Z.; Liu, C.; Wang, C.; Ling, Z.; Wang, Y.; Wang, Y.; Zhang, M.; Chen, S.; Xu, B.; Guan, H.; et al. LncRNA CCAT1 Promotes Prostate Cancer Cell Proliferation by Interacting with DDX5 and MIR-28-5P. Mol. Cancer Ther. 2019, 18, 2469-2479. [CrossRef]

167. Barros-Silva, D.; Lobo, J.; Guimaraes-Teixeira, C.; Carneiro, I.; Oliveira, J.; Martens-Uzunova, E.S.; Henrique, R.; Jeronimo, C. VIRMA-Dependent N6-Methyladenosine Modifications Regulate the Expression of Long Non-Coding RNAs CCAT1 and CCAT2 in Prostate Cancer. Cancers 2020, 12, 771. [CrossRef]

168. Pan, Y.; Chen, J.; Tao, L.; Zhang, K.; Wang, R.; Chu, X.; Chen, L. Long Noncoding RNA ROR Regulates Chemoresistance in Docetaxel-Resistant Lung Adenocarcinoma Cells Via Epithelial Mesenchymal Transition Pathway. Oncotarget 2017, 8, 33144-33158. [CrossRef]

169. Zhang, Y.; Lu, Y.; Zhang, C.; Huang, D.; Wu, W.; Zhang, Y.; Shen, J.; Cai, Y.; Chen, W.; Yao, W. FSCN1 Increases Doxorubicin Resistance in Hepatocellular Carcinoma through Promotion of Epithelial-Mesenchymal Transition. Int. J. Oncol. 2018, 52, 1455-1464.

170. Grochowski, C.M.; Loomes, K.M.; Spinner, N.B. Jagged1 (JAG1): Structure, Expression, and Disease Associations. Gene 2016, 576, 381-384. [CrossRef]

171. Kim, T.M.; Ha, S.A.; Kim, H.K.; Yoo, J.; Kim, S.; Yim, S.H.; Jung, S.H.; Kim, D.W.; Chung, Y.J.; Kim, J.W. Gene Expression Signatures Associated with the In Vitro Resistance to Two Tyrosine Kinase Inhibitors, Nilotinib and Imatinib. Blood Cancer J. 2011, 1, e32. [CrossRef] [PubMed]

172. Naghizadeh, S.; Mohammadi, A.; Duijf, P.H.G.; Baradaran, B.; Safarzadeh, E.; Cho, W.C.; Mansoori, B. The Role of miR-34 in Cancer Drug Resistance. J. Cell. Physiol. 2020. [CrossRef] [PubMed]

173. Li, L.; Wang, Y.; Zhang, X.; Huang, Q.; Diao, Y.; Yin, H.; Liu, H. Long Non-Coding RNA HOXD-AS1 in Cancer. Clin. Chim. Acta 2018, 487, 197-201. [CrossRef] [PubMed] 
174. Kim, J.; Banerjee, T.; Vinckevicius, A.; Luo, Q.; Parker, J.B.; Baker, M.R.; Radhakrishnan, I.; Wei, J.; Barish, G.D.; Chakravarti, D. A Role for WDR5 in Integrating Threonine 11 Phosphorylation to Lysine 4 Methylation on Histone H3 during Androgen Signaling and in Prostate Cancer. Mol. Cell 2014, 54, 613-625. [CrossRef]

175. Zhou, Y.; Xu, S.; Xia, H.; Gao, Z.; Huang, R.; Tang, E.; Jiang, X. Long Noncoding RNA FEZF1-AS1 in Human Cancers. Clin. Chim. Acta 2019, 497, 20-26. [CrossRef]

176. Cui, Y.; Wu, F.; Tian, D.; Wang, T.; Lu, T.; Huang, X.; Zhang, P.; Qin, L. miR-199a-3p Enhances Cisplatin Sensitivity of Ovarian Cancer Cells by Targeting ITGB8. Oncol. Rep. 2018, 39, 1649-1657. [CrossRef]

177. Malric, L.; Monferran, S.; Delmas, C.; Arnauduc, F.; Dahan, P.; Boyrie, S.; Deshors, P.; Lubrano, V.; Da Mota, D.F.; Gilhodes, J.; et al. Inhibiting Integrin Beta8 to Differentiate and Radiosensitize Glioblastoma-Initiating Cells. Mol. Cancer Res. 2019, 17, 384-397. [CrossRef]

178. Wang, W.W.; Wang, Y.B.; Wang, D.Q.; Lin, Z.; Sun, R.J. Integrin Beta-8 (ITGB8) Silencing Reverses Gefitinib Resistance of Human Hepatic Cancer HepG2/G Cell Line. Int. J. Clin. Exp. Med. 2015, 8, 3063-3071.

179. Lian, Y.; Cai, Z.; Gong, H.; Xue, S.; Wu, D.; Wang, K. HOTTIP: A Critical Oncogenic Long Non-Coding RNA in Human Cancers. Mol. Biosyst. 2016, 12, 3247-3253. [CrossRef]

180. Zhang, G.J.; Song, W.; Song, Y. Overexpression of HOTTIP Promotes Proliferation and Drug Resistance of Lung Adenocarcinoma by Regulating AKT Signaling Pathway. Eur. Rev. Med. Pharmacol. Sci. 2017, 21, 5683-5690.

181. Wang, J.; Lv, B.; Su, Y.; Wang, X.; Bu, J.; Yao, L. Exosome-Mediated Transfer of lncRNA HOTTIP Promotes Cisplatin Resistance in Gastric Cancer Cells by Regulating HMGA1/miR-218 Axis. Onco Targets Ther. 2019, 12, 11325-11338. [CrossRef] [PubMed]

182. Li, Z.; Zhao, L.; Wang, Q. Overexpression of Long Non-Coding RNA HOTTIP Increases Chemoresistance of Osteosarcoma Cell by Activating the Wnt/Beta-Catenin Pathway. Am. J. Transl. Res. 2016, 8, 2385-2393. [PubMed]

183. Parolia, A.; Crea, F.; Xue, H.; Wang, Y.; Mo, F.; Ramnarine, V.R.; Liu, H.H.; Lin, D.; Saidy, N.R.N.; Clermont, P.; et al. The Long Non-Coding RNA PCGEM1 is Regulated by Androgen Receptor Activity In Vivo. Mol. Cancer 2015, 14, 1-7. [CrossRef]

184. Prensner, J.R.; Sahu, A.; Iyer, M.K.; Malik, R.; Chandler, B.; Asangani, I.A.; Poliakov, A.; Vergara, I.A.; Alshalalfa, M.; Jenkins, R.B.; et al. The IncRNAs PCGEM1 and PRNCR1 are Not Implicated in Castration Resistant Prostate Cancer. Oncotarget 2014, 5, 1434-1438. [CrossRef] [PubMed]

185. Yang, L.; Lin, C.; Jin, C.; Yang, J.C.; Tanasa, B.; Li, W.; Merkurjev, D.; Ohgi, K.A.; Meng, D.; Zhang, J.; et al. lncRNA-Dependent Mechanisms of Androgen-Receptor-Regulated Gene Activation Programs. Nature 2013, 500, 598-602. [CrossRef] [PubMed]

186. Mukhopadhyay, N.K.; Kim, J.; Cinar, B.; Ramachandran, A.; Hager, M.H.; Di Vizio, D.; Adam, R.M.; Rubin, M.A.; Raychaudhuri, P.; De Benedetti, A.; et al. Heterogeneous Nuclear Ribonucleoprotein K is a Novel Regulator of Androgen Receptor Translation. Cancer Res. 2009, 69, 2210-2218. [CrossRef]

187. Li, Y.; Lv, S.; Ning, H.; Li, K.; Zhou, X.; Xv, H.; Wen, H. Down-Regulation of CASC2 Contributes to Cisplatin Resistance in Gastric Cancer by Sponging miR-19a. Biomed. Pharmacother. 2018, 108, 1775-1782. [CrossRef]

188. Liao, Y.; Shen, L.; Zhao, H.; Liu, Q.; Fu, J.; Guo, Y.; Peng, R.; Cheng, L. LncRNA CASC2 Interacts with miR-181a to Modulate Glioma Growth and Resistance to TMZ through PTEN Pathway. J. Cell. Biochem. 2017, 118, 1889-1899. [CrossRef]

189. Zheng, P.; Dong, L.; Zhang, B.; Dai, J.; Zhang, Y.; Wang, Y.; Qin, S. Long Noncoding RNA CASC2 Promotes Paclitaxel Resistance in Breast Cancer through Regulation of miR-18a-5p/CDK19. Histochem. Cell Biol. 2019, 152, 281-291. [CrossRef]

190. Feng, Y.; Zou, W.; Hu, C.; Li, G.; Zhou, S.; He, Y.; Ma, F.; Deng, C.; Sun, L. Modulation of CASC2/miR-21/PTEN Pathway Sensitizes Cervical Cancer to Cisplatin. Arch. Biochem. Biophys. 2017, 623-624. [CrossRef]

191. Tong, L.; Wu, W. Effects of Long Non-Coding RNA (lncRNA) Cancer Susceptibility Candidate 2c (CASC2c) on Proliferation, Metastasis and Drug Resistance of Non-Small Cell Lung Cancer (NSCLC) Cells through ERK1/2 and Beta-Catenin Signaling Pathways. Pathol. Res. Pract. 2019, 215, 152522. [CrossRef] [PubMed]

192. Zheng, H.C. The Molecular Mechanisms of Chemoresistance in Cancers. Oncotarget 2017, 8, 59950-59964. [CrossRef] [PubMed]

193. Park, J.S.; Kim, J.; Elghiaty, A.; Ham, W.S. Recent Global Trends in Testicular Cancer Incidence and Mortality. Med. Baltim. 2018, 97, e12390. [CrossRef] [PubMed] 
194. Magers, M.J.; Idrees, M.T. Updates in Staging and Reporting of Testicular Cancer. Surg. Pathol. Clin. 2018, 11, 813-824. [CrossRef] [PubMed]

195. Anonymous. International Germ Cell Consensus Classification: A Prognostic Factor-Based Staging System for Metastatic Germ Cell Cancers. International Germ Cell Cancer Collaborative Group. J. Clin. Oncol. 1997, 15, 594-603. [CrossRef]

196. Woldu, S.L.; Bagrodia, A. Update on Epidemiologic Considerations and Treatment Trends in Testicular Cancer. Curr. Opin. Urol. 2018, 28, 440-447. [CrossRef]

197. Regouc, M.; Belge, G.; Lorch, A.; Dieckmann, K.P.; Pichler, M. Non-Coding microRNAs as Novel Potential Tumor Markers in Testicular Cancer. Cancers 2020, 12, 749. [CrossRef]

198. Lembeck, A.L.; Puchas, P.; Hutterer, G.; Barth, D.A.; Terbuch, A.; Bauernhofer, T.; Pichler, M. MicroRNAs as Appropriate Discriminators in Non-Specific Alpha-Fetoprotein (AFP) Elevation in Testicular Germ Cell Tumor Patients. Noncoding RNA 2020, 6, 2. [CrossRef]

199. Raveh, E.; Matouk, I.J.; Gilon, M.; Hochberg, A. The H19 Long Non-Coding RNA in Cancer Initiation, Progression and Metastasis-A Proposed Unifying Theory. Mol. Cancer 2015, 14. [CrossRef]

200. Wang, Y.; Gan, Y.; Tan, Z.; Zhou, J.; Kitazawa, R.; Jiang, X.; Tang, Y.; Yang, J. TDRG1 Functions in Testicular Seminoma are Dependent on the PI3K/Akt/mTOR Signaling Pathway. Onco Targets Ther. 2016, 9, 409-420.

201. Gan, Y.; Wang, Y.; Tan, Z.; Zhou, J.; Kitazawa, R.; Jiang, X.; Tang, Y.; Yang, J. TDRG1 Regulates Chemosensitivity of Seminoma TCam-2 Cells to Cisplatin Via PI3K/Akt/mTOR Signaling Pathway and Mitochondria-Mediated Apoptotic Pathway. Cancer. Biol. Ther. 2016, 17, 741-750. [CrossRef] [PubMed]

202. Zheng, Z.G.; Xu, H.; Suo, S.S.; Xu, X.L.; Ni, M.W.; Gu, L.H.; Chen, W.; Wang, L.Y.; Zhao, Y.; Tian, B.; et al. The Essential Role of $\mathrm{H} 19$ Contributing to Cisplatin Resistance by Regulating Glutathione Metabolism in High-Grade Serous Ovarian Cancer. Sci. Rep. 2016, 6, 26093. [CrossRef] [PubMed]

203. Wang, Q.; Cheng, N.; Li, X.; Pan, H.; Li, C.; Ren, S.; Su, C.; Cai, W.; Zhao, C.; Zhang, L.; et al. Correlation of Long Non-Coding RNA H19 Expression with Cisplatin-Resistance and Clinical Outcome in Lung Adenocarcinoma. Oncotarget 2017, 8, 2558-2567. [CrossRef] [PubMed]

204. Jia, J.; Zhang, X.; Zhan, D.; Li, J.; Li, Z.; Li, H.; Qian, J. LncRNA H19 Interacted with miR-130a-3p and miR-17-5p to Modify Radio-Resistance and Chemo-Sensitivity of Cardiac Carcinoma Cells. Cancer Med. 2019, 8, 1604-1618. [CrossRef] [PubMed]

205. Wu, Y.; Zhou, Y.; He, J.; Sun, H.; Jin, Z. Long Non-Coding RNA H19 Mediates Ovarian Cancer Cell Cisplatin-Resistance and Migration during EMT. Int. J. Clin. Exp. Pathol. 2019, 12, 2506-2515. [PubMed]

206. Shah, M.Y.; Ferrajoli, A.; Sood, A.K.; Lopez-Berestein, G.; Calin, G.A. microRNA Therapeutics in Cancer-An Emerging Concept. EBioMedicine 2016, 12, 34-42. [CrossRef]

207. Dragomir, M.P.; Kopetz, S.; Ajani, J.A.; Calin, G.A. Non-Coding RNAs in GI Cancers: From Cancer Hallmarks to Clinical Utility. Gut 2020, 69, 748-763. [CrossRef]

208. De Los Santos, M.C.; Dragomir, M.P.; Calin, G.A. The Role of Exosomal Long Non-Coding RNAs in Cancer Drug Resistance. Cancer. Drug Resist. 2019, 2, 1178-1192. [CrossRef]

209. Pardini, B.; Sabo, A.A.; Birolo, G.; Calin, G.A. Noncoding RNAs in Extracellular Fluids as Cancer Biomarkers: The New Frontier of Liquid Biopsies. Cancers 2019, 11, 1170. [CrossRef]

(C) 2020 by the authors. Licensee MDPI, Basel, Switzerland. This article is an open access article distributed under the terms and conditions of the Creative Commons Attribution (CC BY) license (http://creativecommons.org/licenses/by/4.0/). 